\title{
Impacts of aerosol-cloud interactions on past and future changes in tropospheric composition
}

\author{
N. Unger ${ }^{1,2}$, S. Menon ${ }^{3}$, D. M. Koch ${ }^{1}$, and D. T. Shindell ${ }^{1}$ \\ ${ }^{1}$ NASA Goddard Institute for Space Studies, New York, NY, USA \\ ${ }^{2}$ Columbia University, New York, NY, USA \\ ${ }^{3}$ Lawrence Berkeley National Laboratory, Berkeley, CA, USA
}

Received: 20 January 2009 - Published in Atmos. Chem. Phys. Discuss.: 24 February 2009

Revised: 27 May 2009 - Accepted: 28 May 2009 - Published: 22 June 2009

\begin{abstract}
The development of effective emissions control policies that are beneficial to both climate and air quality requires a detailed understanding of all the feedbacks in the atmospheric composition and climate system. We perform sensitivity studies with a global atmospheric composition-climate model to assess the impact of aerosols on tropospheric chemistry through their modification on clouds, aerosol-cloud interactions (ACI). The model includes coupling between both tropospheric gas-phase and aerosol chemistry and aerosols and liquid-phase clouds. We investigate past impacts from preindustrial (PI) to present day (PD) and future impacts from PD to 2050 (for the moderate IPCC A1B scenario) that embrace a wide spectrum of precursor emission changes and consequential ACI. The aerosol indirect effect (AIE) is estimated to be $-2.0 \mathrm{Wm}^{-2}$ for PD-PI and $-0.6 \mathrm{Wm}^{-2}$ for 2050-PD, at the high end of current estimates. Inclusion of ACI substantially impacts changes in global mean methane lifetime across both time periods, enhancing the past and future increases by $10 \%$ and $30 \%$, respectively. In regions where pollution emissions increase, inclusion of ACI leads to $20 \%$ enhancements in in-cloud sulfate production and $\sim 10 \%$ enhancements in sulfate wet deposition that is displaced away from the immediate source regions. The enhanced in-cloud sulfate formation leads to larger increases in surface sulfate across polluted regions $(\sim 10-30 \%)$. Nitric acid wet deposition is dampened by $15-$ $20 \%$ across the industrialized regions due to ACI allowing additional re-release of reactive nitrogen that contributes to 1-2 ppbv increases in surface ozone in outflow regions. Our model findings indicate that ACI must be considered in stud-
\end{abstract}

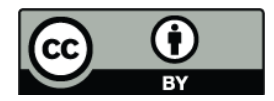

Correspondence to: N. Unger (nunger@giss.nasa.gov) ies of methane trends and projections of future changes to particulate matter air quality.

\section{Introduction}

Chemistry-aerosol-climate interactions represent one of the most important and most difficult foci of global change research. On the one hand, a significant part of the current human-made radiative forcing occurs through chemically active species, the most important of which are tropospheric ozone $\left(\mathrm{O}_{3}\right)$ and fine aerosol particles including sulfate, black carbon (BC) and organic carbon (OC). On the other hand, changes in climate can lead to changes in the chemical composition of the atmosphere both by altering emissions and through changes in the chemical processes that occur in the atmosphere. Furthermore, coupling between gas and aerosol systems, especially $\mathrm{O}_{3}$ and sulfate can influence both composition and climate change (Unger et al., 2006a).

Aerosols affect tropospheric chemical composition through a number of pathways. In polluted regions, aerosols usually act to suppress photochemistry by decreasing available photochemically active radiation and providing surfaces for heterogeneous reaction processes, effects that have been reasonably well studied (e.g. Dentener et al., 1993; Tie et al., 2003; Martin et al., 2003; Liao and Seinfeld, 2005). It is essential to include such effects of aerosols in global atmospheric chemistry models in order to reconcile simulations of $\mathrm{O}_{3}$ and precursors with observations. Aerosol direct radiative forcing may also influence chemical composition by driving changes in meteorological parameters including temperature, precipitation and winds (e.g. Chen et al., 2007). Whilst research is emerging to quantify the climate response to changes in aerosol loading (e.g. Jones et al., 2007; Koch et

Published by Copernicus Publications on behalf of the European Geosciences Union. 
al., 2009), feedbacks to chemical composition and surface air quality are less well studied. The radiative effects of clouds on tropospheric photochemistry on the global average have been found to be only modest, the dominant effect being to influence the vertical redistribution of the intensity of photochemical activity (Liu et al., 2006). To our knowledge, the impact of aerosols on tropospheric chemistry through their modification on clouds remains poorly quantified. A recent model study found that the aerosol-induced cloud changes for the near future 2030 to present day time period may decrease $\mathrm{O}_{3}$ forcing by up to $20 \%$ globally (Menon et al., 2008a). Therefore such cloud-aerosol-chemistry interactions warrant further examination.

Aerosol-cloud interactions (ACI) that give rise to the "aerosol indirect effect" (AIE) are usually split into two effects: (a) the first aerosol indirect effect: increased (decreased) cloud reflectivity due to an increase (decrease) in aerosols and cloud droplet number concentrations (CDNC) and reduced (increased) droplet sizes for the same liquid water content (LWC) (Twomey, 1991); and (b) the second aerosol indirect effect: change in cloud cover (CC), cloud liquid water path (LWP) and precipitation due to smaller droplet sizes that inhibit precipitation processes, thereby increasing CC and LWP (and thus cloud optical depths) (Albrecht, 1989). ACI may influence photochemistry and composition through several pathways. Changes to available radiation fields may impact photolysis frequencies and changes to cloud lifetime and precipitation may alter rates of in-cloud processing and wet deposition of pollutants and precursors. Furthermore, ACI can influence meteorological factors such as surface air temperature due to cloud cover change. In turn, all of these cloud effects on chemistry will influence $\mathrm{O}_{3}$, sulfate and methane $\left(\mathrm{CH}_{4}\right)$ lifetime. The overall impact of ACI on composition is complex due to effects of competing sign and cannot be determined without a 3-dimensional global model that includes all processes and feedbacks interactively.

We apply a state-of-the-art global atmospheric composition and climate model to simulate three time periods: preindustrial (PI), present day (PD) and a future world at 2050. For each time slice, two simulations are performed: the first includes an interactive treatment of ACI (allowing CDNC to change with changing aerosol concentrations) and the second uses fixed CDNC. With fixed CDNC, cloud droplet size and optical properties are mainly dependent on cloud condensate, whereas for the interactive ACI treatment, both CDNC and cloud condensate determine cloud droplet size and cloud optical properties. Differences between the sensitivity simulations provide assessment of the impact of ACI on composition. The PD-PI change (labeled "past") features a large increase in anthropogenic aerosol loading across the polluted Northern Hemisphere and therefore substantial aerosol-cloud effects. For the 2050 future projection, the IPCC SRES A1B emissions scenario is selected. The 2050-PD change (labeled "future") features more complex regional shifts in gas and aerosol precursor emissions, and consequently ACI, with decreases at Northern Hemisphere mid-latitudes and increases in subtropical developing regions. The 2050 A1B scenario has already been the focus of chemistry-climate studies that have investigated the climate response due to $\mathrm{O}_{3}$ and aerosol pollution (Shindell et al., 2007) and future changes to surface air quality over the US (Wu et al., 2008). Here, we extend these previous analyses by probing the role of aerosolinduced cloud changes in affecting the composition.

The goal of this study is to quantify the impacts of ACI on tropospheric chemistry and composition for past and future changes where there are substantial changes in aerosol loading. We focus on several composition parameters that are likely to be sensitive to changes in clouds. The photolysis of $\mathrm{O}_{3}$ yields excited state oxygen atoms, $\mathrm{O}\left({ }^{1} \mathrm{D}\right)$, that react with water vapor $\left(\mathrm{H}_{2} \mathrm{O}\right)$ to form the hydroxyl radical $(\mathrm{OH})$, the major tropospheric oxidizing agent. This reaction pathway is the most important direct source of $\mathrm{OH}$ and therefore key in the photochemical processing that may lead to $\mathrm{O}_{3}$ formation or destruction and controls the lifetime of $\mathrm{CH}_{4}$. The rate of this photolysis process $\left(\mathrm{J}\left(\mathrm{O}^{1} \mathrm{D}\right)\right)$ is dependent on available incoming ultra violet radiation and therefore susceptible to cloud changes. In-cloud formation of sulfate aerosol may represent $50 \%$ of the total production budget globally, although the importance may be higher in polluted regions (Koch et al., 2006). Wet deposition is a key loss process for many trace species, especially nitric acid $\left(\mathrm{HNO}_{3}\right)$ that represents radical termination in $\mathrm{O}_{3}$ formation chemistry, and aerosols and therefore strongly affects the ground level distribution of these pollutants.

In Sect. 2 we describe the methodology including: Atmospheric composition-climate model (2.1), Emissions (2.2) and Simulations (2.3). In Section 3 we present analysis of the simulation results including: Past and future aerosol-cloud interactions (3.1), Aerosol distributions and impacts on cloud properties (3.1.1), Aerosol direct radiative forcing and AIE (3.1.2), Impacts of aerosol-cloud interactions on precipitation and temperature (3.1.3), Impacts of $\mathrm{ACI}$ on $\mathrm{J}\left(\mathrm{O}^{1} \mathrm{D}\right)$ photolysis rate (3.2), Impacts of ACI on zonal mean $\mathrm{OH}$ and global mean $\mathrm{CH}_{4}$ lifetime (3.3), Impacts of ACI on sulfate in-cloud production and wet deposition (3.4), Impacts of ACI on surface air quality (3.5), and Impacts of ACI on radiative forcing (3.6). In Section 4 we present conclusions and recommendations.

\section{Methodology}

\subsection{Atmospheric composition-climate model descrip- tion}

We applied the NASA Goddard Institute for Space Studies (GISS) model for Physical Understanding of CompositionClimate INteractions and Impacts (GISS-PUCCINI) described in detail and comprehensively evaluated in Shindell 
et al. (2006). The model comprises the GISS version ModelE general circulation model (Schmidt et al., 2006) with embedded fully interactive photochemistry and aerosol modules. The version used here includes sulfate, black carbon (BC), organic carbon (OC) and sea salt with coupling between the gas-phase chemistry and sulfate aerosol modules (Bell et al., 2005). Nitrate represents only a small component of the anthropogenic inorganic aerosol (e.g. Forster et al., 2007) and is not included in this study. Since nitrate aerosol is formed from $\mathrm{HNO}_{3}$, this omission likely leads to only modest overestimates of the impacts on $\mathrm{HNO}_{3}$ and therefore $\mathrm{O}_{3}$ based on our previous findings (Bauer et al., 2007).

We use 23 vertical layers (model top in the mesosphere) and $4 \times 5$ degree latitudinal by longitudinal horizontal resolution. Chemical calculations are performed only in the troposphere in the present version of the model. We use a thermal tropopause defined by the meteorological lapse rate. Stratospheric values of $\mathrm{O}_{3}, \mathrm{NO}_{\mathrm{x}}$ and $\mathrm{CH}_{4}$ are prescribed according to satellite observations with seasonally varying abundances (Shindell et al., 2003). Photolysis rates are calculated using the FAST-J2 scheme (Bian and Prather, 2002). The wet deposition scheme is described in detail in Koch et al. (1999). Briefly, soluble gases and aerosols can be removed into either moist convective plumes or large-scale clouds as derived from the GCM's internal cloud scheme (Del Genio and Yao, 1993). During convection, all chemical species are transported along with the convective plumes, with scavenging of soluble species within and below cloud updrafts. In largescale stratiform clouds, soluble gases are removed based on the fraction of the grid box over which precipitation is taking place. Washout of soluble species is calculated below precipitating clouds. The model includes a dissolved species budget (Koch et al., 2006) for stratiform clouds that makes the simulation more faithful to the cloud scheme and more physically realistic.

The model performance with respect to key short-lived tracers has been comprehensively evaluated for $\mathrm{O}_{3}$, nitrogen species, and reduced carbon species (Shindell et al., 2006), CO (Shindell et al., 2005) and sulfate and sea salt aerosols (Koch et al., 2006) and carbonaceous aerosols (Koch et al., 2007). Tropospheric $\mathrm{O}_{3}$ is well simulated, especially in the vicinity of the tropopause, where it has the greatest effect on climate, and at the surface, where is affects air quality, with an average bias of only $6 \%$ against a comprehensive ozonesonde dataset (Shindell et al., 2006). The tropospheric chemistry version of GISS-PUCCINI performed well in a recent multi-model intercomparison involving evaluation against ozonesonde climatology, with a root-meansquare (rms) error value of $6.3 \mathrm{ppbv}$ compared with a range of rms error values of 4.6 to $17.0 \mathrm{ppbv}$ (Stevenson et al., 2006). Comparisons of the vertical profiles of $\mathrm{NO}_{\mathrm{x}}$ and nitric acid $\left(\mathrm{HNO}_{3}\right)$ show good agreement between the model and observations from a variety of aircraft measurements across many regions (Shindell et al., 2006). The model's simulation of $\mathrm{CO}$ has been compared extensively with both surface and satellite observations (Shindell et al., 2005). It shows good agreement in both magnitude and seasonality, suggesting that the model's hydroxyl radical fields are reasonably realistic. Monthly mean correlations against mid-tropospheric satellite observations from MOPITT (Measurements of Pollution in the Troposphere) were typically in the range of 0.8-0.9. The sulfate model is generally within a factor of 2 of observations (Koch et al., 2006). Model sulfate at remote sites is generally less than observed. Carbonaceous aerosols are also typically within a factor of 2 of surface concentration observations, but are underestimated by more than a factor of 5 in Southeast Asia.

The direct instantaneous top-of-the-atmosphere (TOA) radiative forcing by the short-lived pollutants $\left(\mathrm{O}_{3}\right.$, sulfate, $\mathrm{BC}$ and $\mathrm{OC}$ ) is calculated internally within the climate model's radiation scheme (Schmidt et al., 2006). The aerosols are assumed to be externally mixed. Additional details on optical and radiative schemes are provided in Koch et al. (2006). The schemes used to treat the ACI, coupling between aerosols and cloud microphysics for liquid-phase stratus and cumulus clouds, are described in detail in Menon and Rotstayn (2006). Essentially, separate relationships are used to describe the coupling between aerosols and liquid-phase stratiform and convective clouds. Aerosol mass concentrations are converted to aerosol number concentrations assuming lognormal distributions and are related to CDNC through empirical equations. Additionally, effects of changes to cloud cover and turbulence on CDNC are also included. To represent aerosol effects on precipitation, the autoconversion scheme in the model is modified to include a dependence on droplet size (as well as CDNC and droplet dispersion effects) such that autoconversion is triggered if droplet sizes exceed $14 \mu \mathrm{m}$ as described in Rotstayn and Liu (2005). In the standard scheme, without ACI, autoconversion is an increasing function of cloud condensate. The AIE is estimated based on the difference in net cloud radiative forcing between time periods (Menon et al., 2002).

Model simulated ACI have been evaluated with satellitebased retrievals to constrain the magnitude of the AIE (Menon et al. 2008b). Results indicate that the AIE may be over-predicted over the ocean regions due to an underprediction of cloud droplet size and an over-prediction of cloud optical depth. Simulated CDNC was found to be within satellite retrieved uncertainty. Over land locations, coincident retrievals of aerosols and cloud properties are not easily available from satellites and thus evaluation of changes to cloud properties from aerosols is more difficult. Over some land locations such as the Arctic, model-simulated values of the CDNC have been found to be too large, compared to satellite-retrievals, though COD and effective radii were within the observed range (Menon et al. 2008a). A more meaningful global evaluation of the AIE is challenging in the absence of global observations of CDNC that serve as the main link between aerosols and cloud properties. 
Table 1. Total and anthropogenic precursor emissions of $\mathrm{CO}\left(\mathrm{Tg} \mathrm{yr}^{-1}\right), \mathrm{NO}_{\mathrm{x}}\left(\mathrm{Tg} \mathrm{Nyr}^{-1}\right), \mathrm{NMVOC}\left(\mathrm{TgC} \mathrm{yr}^{-1}\right), \mathrm{SO}_{2}$ $\left(\operatorname{Tg~S~yr}^{-1}\right)$, BC $\left(\operatorname{Tg~yr}^{-1}\right), \mathrm{OC}\left(\mathrm{Tg} \mathrm{yr}^{-1}\right)$ used in each time slice. Biomass burning is classified as anthropogenic. Prescribed $\mathrm{CH}_{4}$ concentrations (ppbv) are also indicated.

\begin{tabular}{lccc}
\hline Total Emission & PI & PD & 2050 A1B \\
\hline $\mathrm{CO}$ & 30 & 847 & 1146 \\
$\mathrm{NO}_{\mathrm{x}}$ & 13 & 46 & 77 \\
$\mathrm{NMVOC}_{\mathrm{SO}_{2}}$ & 579 & 707 & 759 \\
$\mathrm{BC}$ & 11 & 84 & 82 \\
$\mathrm{OC}$ & 0.4 & 8 & 6 \\
$\mathrm{Anthropogenic} \mathrm{Emission}$ & 20 & 58 & 51 \\
$\mathrm{CO}$ & & & \\
$\mathrm{NO}$ & 30 & 847 & 1146 \\
$\mathrm{NMVOC}_{\mathrm{SM}}$ & 0.4 & 33 & 65 \\
$\mathrm{SO}$ & 2 & 132 & 192 \\
$\mathrm{BC}$ & 0.1 & 73 & 71 \\
OC & 0.4 & 8 & 6 \\
Prescribed $\mathrm{CH}_{4}$ concentration & 3 & 42 & 35 \\
Northern Hemisphere & 790 & 1850 & 2932 \\
Southern Hemisphere & 790 & 1720 & 2780 \\
\hline
\end{tabular}

\subsection{Emissions}

Table 1 indicates the trace gas and aerosol precursor emissions inventories used for the PD, PI and 2050 simulations. For PD, we used anthropogenic $\mathrm{CO}, \mathrm{NO}_{\mathrm{x}}, \mathrm{NMVOCs}$ and $\mathrm{SO}_{2}$ emissions from the Emissions Database for Global Atmospheric Research (EDGAR3.2) for the year 1995 (Olivier and Berdowski, 2001). BC and OC emissions are not available in the EDGAR3.2 database and we used values from another global inventory for the year 1996 (Bond et al., 2004). The emissions include all anthropogenic fossil fuel, biofuel and biomass sources. Natural precursor and aerosol emissions are prescribed according to conventional estimates detailed elsewhere (Unger et al., 2006b). The conventional approach to PI emissions is adopted. We switch off all anthropogenic fossil and biofuel emissions and reduce biomass burning to $10 \%$ of PD values. The 2050 A1B emissions scenario is described in further detail in Shindell et al. (2007).

\subsection{Simulations}

Two sensitivity simulations were run for each of three time periods: PD, PI and future 2050, described in Table 2. The first set of models runs: Sim PD_ACI, Sim PI_ACI, Sim 2050_ACI, include interactive treatment of aerosol-cloud coupling. The second set of model runs: Sim PD, Sim PI, Sim 2050, use fixed CDNC $\left(60 \mathrm{~cm}^{-3}\right.$ over ocean and $174 \mathrm{~cm}^{-3}$ over land).
Table 2. Description of simulations.

\begin{tabular}{lcccc}
\hline Name & Description & Emissions & Climate & ACI \\
\hline Sim PD_ACI & Present day & 1995 & $1990 \mathrm{~s}$ & ON \\
Sim PD & & & & OFF \\
Sim PI_ACI & Preindustrial & $\sim 1850$ & $1880 \mathrm{~s}$ & ON \\
Sim PI & & & & OFF \\
Sim 2050_ACI & Future 2050 & 2050 & $2050 \mathrm{~s}$ & ON \\
Sim 2050 & & & & OFF \\
\hline
\end{tabular}

For the PI, PD and 2050 simulations we use monthly mean sea surface temperatures and sea ice climatologies for 1876 1885 (Rayner et al., 2003), 1990-1999 (Rayner et al., 2003) and 2050-2059 (IPCC A1B scenario) (Hansen et al., 2007), respectively. Thus, both emission changes and physical climate change effects are included. Clouds will be affected by changes in both aerosol loading and changes in sea surface temperatures and both types will impact the chemistry. Our sensitivity study approach allows isolation of the impacts of the aerosol-induced cloud changes only on composition since both experiments in each time slice use the same sea surface temperature (SST) and sea ice climatologies. Switching on ACI will influence dynamics and meteorological factors such as precipitation and temperature due to cloud cover change that can also affect composition. Thus, in the experimental setup employed here, we have essentially decoupled the meteorological changes driven by ACI from climate changes driven by greenhouse gases (GHGs) and direct aerosol effects. In reality, these effects are coupled to each other, although recent work suggests that the climate response to GHG and aerosols forcings may be additive (Kloster et al., 2009).

$\mathrm{CH}_{4}$ concentrations used for the different time periods are included in Table 1. For PD and 2050 conditions, $\mathrm{CH}_{4}$ concentration is prescribed to hemisphere average values that were generated in previous simulations with a similar model but using a fully interactive $\mathrm{CH}_{4}$ cycle (Unger et al., 2006b; Shindell et al., 2007). For PI, $\mathrm{CH}_{4}$ is fixed to the observed concentrations from ice core records.

All the simulations were run for 12 model years with the same emissions each year, but with GCM meteorological interannual variability; the first 2 years of the simulations allow for the chemistry to adjust from initial conditions and are discarded as spin-up and the remaining 10 years are averaged for analysis.

\section{Results}

Differences between the two sensitivity simulations in the same time slice are dependent on the choice of fixed CDNC, therefore may be somewhat arbitrary. Our focus here is the impact of changing aerosol loading on clouds and feedbacks 

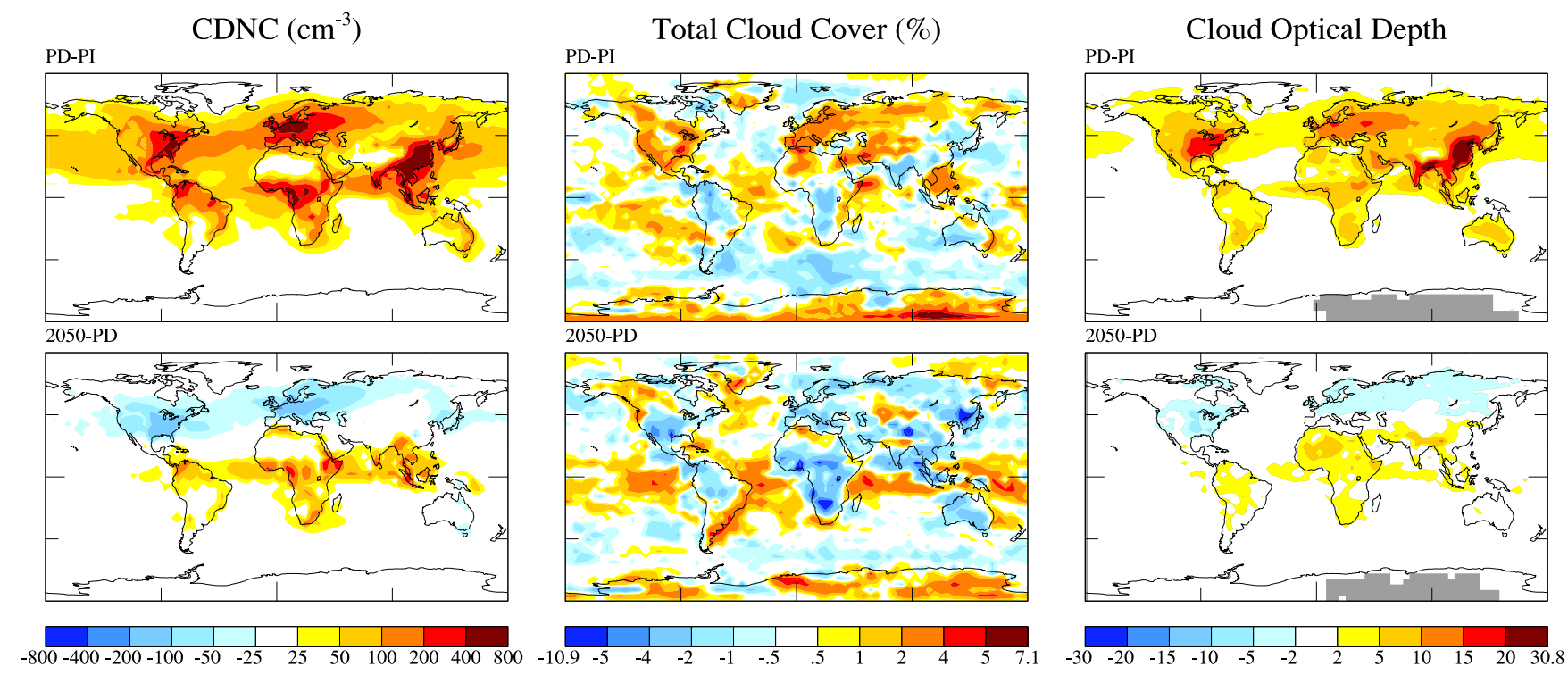

Fig. 1. Difference in annual average cloud droplet number concentration (CDNC) in $\mathrm{cm}^{-3}$, total cloud cover in $\%$ and cloud optical depth (COD) for the past (top row) and future (bottom row) cases.

Table 3. Aerosol column densities for the simulations with aerosolcloud interactions included for the global domain and key source regions.

\begin{tabular}{lccc}
\hline Domain and time slice & Sulfate $\left(\mathrm{mg} \mathrm{m}^{-2}\right)$ & $\mathrm{BC}\left(\mathrm{mg} \mathrm{m}^{-2}\right)$ & $\mathrm{OC}\left(\mathrm{mg} \mathrm{m}^{-2}\right)$ \\
\hline Global & & & \\
PI & 1.43 & 0.014 & 0.58 \\
PD & 2.93 & 0.31 & 1.91 \\
2050A1B & 3.48 & 0.23 & 1.6 \\
North America & & & \\
PI & 1.35 & 0.007 & 0.847 \\
PD & 5.40 & 0.383 & 2.04 \\
2050A1B & 4.36 & 0.23 & 1.51 \\
Europe & & & \\
PI & 1.50 & 0.004 & 0.554 \\
PD & 5.37 & 0.43 & 1.55 \\
2050A1B & 4.83 & 0.26 & 1.3 \\
East Asia & & & \\
PI & 0.89 & 0.009 & 0.555 \\
PD & 3.96 & 0.637 & 2.38 \\
2050A1B & 5.70 & 0.37 & 1.77 \\
\hline
\end{tabular}

to composition across time periods. In order to isolate the impacts of past and future ACI on the change in a composition variable, we take the difference between the change in variable $(\mathrm{X})$ between the two time periods for simulations that include ACI versus the simulations that do not include ACI e.g. [(Sim PD_ACI(X) - Sim PI_ACI (X)) - (Sim PD(X) - Sim PI(X))]. The statistical significance of the difference is determined relative to the model's interannual meteorological variability over the 10 model run years.

\subsection{Past and future aerosol-cloud interactions (ACI)}

\subsubsection{Aerosol distributions and impacts on cloud prop- erties}

Table 3 shows the aerosol column densities for the time periods of interest. Human activities have led to a huge increase in aerosol loading in the atmosphere especially over polluted source regions. Globally, for the PD-PI change, there is a $100 \%$ increase in sulfate, $200 \%$ increase in OC and $2000 \%$ increase in BC, regional increases in polluted regions are more dramatic. The changes in aerosol loading are more complex for the future change. Sulfate loading increases by around $20 \%$ globally and $40 \%$ over East Asia, but decreases over North America $(-20 \%)$ and Europe $(-10 \%)$. BC loading decreases by $-25 \%$ globally and by around $-40 \%$ across all of the regions, mainly due to reductions in emissions from fossil and biofuel sources. Similarly, OC loading decreases globally and over Europe by $-15 \%$ with larger decreases of up to $-25 \%$ across North America and Asia. We do not dwell here on analysis of past and future changes in composition since these have been extensively examined previously in the GISS model for PD-PI (Shindell et al., 2003; Koch et al., 1999) and 2050-PD (Shindell et al., 2007; Koch et al., 2007).

The influences of the changes in human-made aerosol loading on cloud properties are indicated in Table 4. The PD-PI increases in global average CDNC, LWP and COD and coincident decrease in cloud droplet effective radius $\left(R_{\text {eff }}\right)$ are consistent with prior studies using similar treatment of ACI in the GISS model (Menon and Del Genio, 2007). As expected CC increased from PI to PD due to ACI. Without including aerosol-induced changes to clouds, 
Table 4. Global and regional average cloud variables (cloud droplet number concentration [CDNC], effective radius [Reff], liquid water path [LWP], cloud optical depth [COD] and cloud cover [CC]) for the simulations with aerosol-cloud interactions included. Results for simulations without aerosol-cloud interactions are in brackets. In the simulations without aerosol-cloud interactions switched on CDNC is fixed to $60 \mathrm{~cm}^{-3}$ over ocean and $174 \mathrm{~cm}^{-3}$ over land. For CC, values for both total and low CC are indicated.

\begin{tabular}{lcccccc}
\hline Domain and time slice & CDNC $\left(\mathrm{cm}^{-3}\right)$ & Reff $(\mu \mathrm{m})$ & LWP $\left(\mathrm{g} / \mathrm{m}^{2}\right)$ & COD & Total CC $(\%)$ & Low CC $(\%)$ \\
\hline Global & & & & & & \\
PI & 80.7 & 21.5 & $59(83)$ & $10.3(15.2)$ & $64.61(65.05)$ & $54.34(54.62)$ \\
PD & 145.6 & 20.7 & $63(84)$ & $13.1(15.2)$ & $64.74(64.78)$ & $54.52(54.30)$ \\
2050A1B & 150.0 & 21.2 & $66(87)$ & $13.32(15.5)$ & $65.07(65.21)$ & $55.03(54.91)$ \\
North America & & & & & & \\
PI & 58.8 & 17.3 & $44(73)$ & $11.4(20.0)$ & $51.52(52.25)$ & $39.49(40.02)$ \\
PD & 221.4 & 16.0 & $54(74)$ & $19.4(20.0)$ & $52.70(53.20)$ & $40.72(40.86)$ \\
2050A1B & 200.3 & 18.3 & $60(88)$ & $18.2(20.7)$ & $55.86(56.74)$ & $44.53(45.16)$ \\
Europe & & & & & & \\
PI & 68.3 & 18.0 & $41(73)$ & $9.9(17.6)$ & $68.27(70.32)$ & $59.21(61.70)$ \\
PD & 245.5 & 16.5 & $56(74)$ & $16.2(17.7)$ & $69.26(69.70)$ & $60.48(60.70)$ \\
2050A1B & 174.5 & 16.3 & $51(76)$ & $14.9(19.0)$ & $69.71(70.76)$ & $60.89(61.76)$ \\
East Asia & & & & & & \\
PI & 83.8 & 24.1 & $78(117)$ & $13.3(20.7)$ & $63.85(64.38)$ & $47.29(47.34)$ \\
PD & 288.9 & 21.3 & $92(115)$ & $22.4(20.5)$ & $64.03(63.81)$ & $47.66(46.67)$ \\
2050A1B & 300.0 & 19.8 & $87(117)$ & $22.9(20.9)$ & $60.90(61.63)$ & $46.88(46.66)$ \\
\hline
\end{tabular}
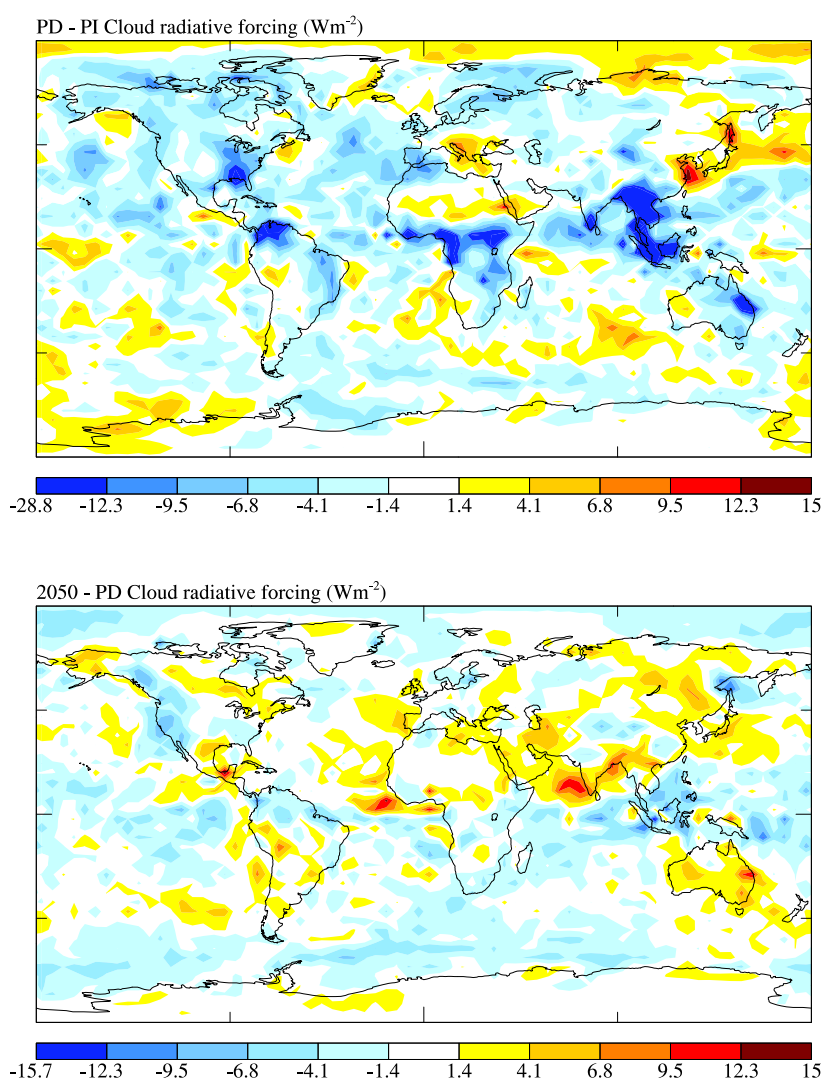

Fig. 2. Annual average cloud radiative forcing for PD-PI (top panel) and 2050-PD (bottom panel) in $\mathrm{Wm}^{-2}$.
CC decreases between PD and PI, due to climate-related changes that tend to decrease CC with increased GHG warming, as also found by Koch et al. (2009). Figure 1 shows the spatial distribution of the aerosol-induced changes in cloud properties between PD-PI and 2050-PD. Changes in CDNC are consistent with changes in aerosol concentrations. For the future case, areas where aerosol concentrations decrease (e.g. North America, Europe) indicate a decrease in CDNC. Over East Asia and the biomass burning regions, CDNC increases due to an increase in aerosols (industrial over Asia and biomass for South America and Africa). Although COD increases/decreases in areas where CDNC increase/decrease, as expected, $\mathrm{CC}$ changes do not follow a similar pattern. For the PD-PI simulations, large changes in CDNC $(\sim 80 \%)$ result in an increase in total and low CC $(0.13 \%$ and $0.18 \%$, respectively), even though climate-related changes tend to decrease CC. For the future scenario, CDNC is approximately the same and thus $\mathrm{CC}$ changes are more determined by climate-related changes, as indicated by $\mathrm{CC}$ changes for simulations without ACI. Menon et al. (2008b) found that CC changes, due to ACI, were more strongly dependent on meteorological changes than on aerosol-induced changes. Similar effects are observed in these simulations. Thus, the ACI influence is relatively small for the future scenario as compared to the changes obtained for the past (PD-PI) simulations.

\subsubsection{Aerosol direct radiative forcing and AIE}

The resultant aerosol direct radiative forcings for the past (PD-PI) and future (2050-PD) time periods are included in Table 5. In this version of the model the past direct 
Table 5. Radiative forcings in $\mathrm{Wm}^{-2}$ for past and future changes calculated using simulations that have AICI switched on (bracketed values are for simulations without AIE).

\begin{tabular}{lll}
\hline Climate forcing agent & Radiative forcing PD-PI & Radiative forcing 2050-PD \\
\hline Ozone & $+0.338(+0.349)$ & $+0.217(+0.215)$ \\
Sulfate & $-0.305(-0.308)$ & $-0.113(-0.122)$ \\
BC & $+0.313(+0.324)$ & $-0.091(-0.097)$ \\
OC & $-0.111(-0.111)$ & $+0.025(+0.026)$ \\
Total Aerosol Direct & $-0.103(-0.095)$ & $-0.179(-0.193)$ \\
Aerosol Indirect Effect & -2.001 & -0.601 \\
\hline
\end{tabular}

aerosol forcing is $-0.11 \mathrm{Wm}^{-2}$ since the negative sulfate and positive BC forcings largely cancel each other out. For the future scenario, where there are more complex spatial changes in aerosol loading, the net aerosol direct forcing is larger than for the past change by about a factor of 1.7 $\left(-0.18 \mathrm{Wm}^{-2}\right)$ because the carbonaceous aerosol direct forcings are so small, despite a sulfate direct forcing only around one third of the PD-PI effect.

We estimate the AIE by taking the difference in net cloud radiative forcing between time periods (Figure 2) for the simulations with ACI and the simulations without. The past AIE is $-2.0 \mathrm{Wm}^{-2}$, higher than previous GISS model estimates (Menon et al., 2008a; Koch et al., 2009) and estimates based on constraints from the temperature record using a parameterized AIE treatment in a similar version of the GISS model (Hansen et al., 2005). However, changes in CDNC in the Koch et al. (2009) simulations are about half of that obtained in this study since the Koch et al. study used a different set of emissions that had a lower sulfate burden change. Also, in the Koch et al. study, biomass burning emissions were set to half present day values for the PI simulation whereas in this study biomass burning emissions are only $10 \%$ of present day values. Thus, the AIE we obtain is high but within the range predicted by other studies that vary from 0.5 to $-2.0 \mathrm{Wm}^{-2}$ for both indirect effects (Lohmann and Feichter, 2005). Forster et al. (2007) give a current best estimate of the range $\left(-1.1\right.$ to $\left.+0.4 \mathrm{Wm}^{-2}\right)$ and median value $\left(-0.70 \mathrm{Wm}^{-2}\right)$ from a multi-model assessment of the cloud albedo effect only. Our simulations include both indirect effects and are thus larger.

\subsubsection{Impacts of ACI on precipitation and temperature}

Figure 3 shows precipitation changes due to the prescribed SST and sea ice boundary conditions as well as the impacts on those precipitation changes when including online ACI. Without ACI, global annual mean precipitation increases by $+0.02 \pm 0.006 \mathrm{~mm} /$ day for the past case and $+0.13 \pm 0.008 \mathrm{~mm} /$ day for the future case. The well-known spatial pattern of the precipitation changes expected due to GHG-induced warming (from the prescribed SSTs) is ev- ident: increases in tropics and drying in subtropics. In both the past and future cases, inclusion of ACI tend to increase the global annual mean precipitation change slightly although neither result is statistically significant even at the global scale. For the past case, the impact of ACI is $+0.005 \pm 0.009 \mathrm{~mm} /$ day and for the future case is $0.004 \pm 0.014 \mathrm{~mm} /$ day. None of the regional impacts in Fig. 3 are $95 \%$ statistically significant, however, there are suggestions of ACI influence that tends to either reinforce or counteract the rainfall changes induced from the prescribed SSTs (driven by GHG increases). Tropical precipitation changes correlate with the cloud cover changes (Fig. 1). In general, where aerosol pollution increases across the time period, ACI cause increases in liquid water path (not shown) and impose decreases in rainfall and vice versa, Thus, ACI appear to have a drying influence on the PD-PI change on the US east coast region of around $0.3-0.5 \mathrm{~mm} /$ day. Drying also occurs over the biomass burning regions due to inclusion of ACI up to 1-2 mm/day. The PD-PI drying over South and Southeast Asia is strengthened when ACI are included, which also may be related to a southward shift in the Intertropical Convergence Zone (e.g. Jones et al., 2007). In contrast, over Europe, ACI cause increases in the PD-PI change by around $0.1-0.3 \mathrm{~mm} /$ day that are mainly due to increases in convective precipitation there (not shown). In the future case, there is evidence of ACI leading to precipitation increases over the southeastern US up to $0.5 \mathrm{~mm} / \mathrm{day}$. ACI cause increased precipitation over the Middle East and South Asia by 0.3$0.5 \mathrm{~mm} /$ day and decreased precipitation in Pacific outflow regions by around $0.5 \mathrm{~mm} /$ day.

Figure 4 shows surface air temperature (SAT) changes due to the prescribed SST and sea ice boundary conditions and the impacts of ACI on the SAT changes. Without ACI, the global mean SAT change for the past is $0.63 \pm 0.02^{\circ} \mathrm{C}$ and for the future is $1.1 \pm 0.06^{\circ} \mathrm{C}$. The effects of ACI on SAT are expected to be only small because prescribed SSTs largely determine the SAT (ACI effects on SAT would be larger if full climate feedbacks were allowed in the simulations). Thus, largest ACI effects on SAT occur over continents where SSTs have less influence. Including ACI for the past case, generally decreases SAT over the continental 

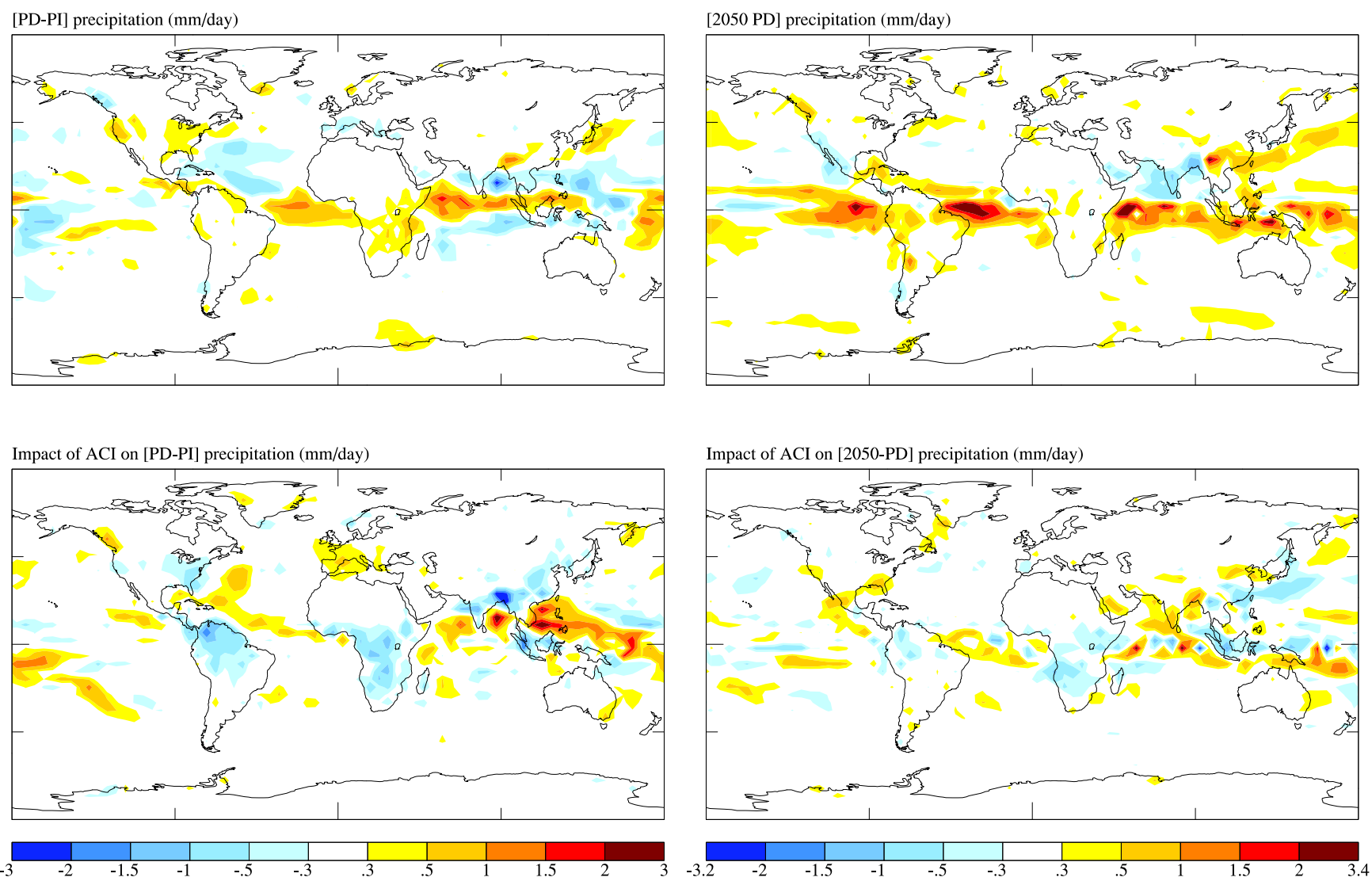

Fig. 3. Annual average precipitation change for past (top left) and future (top right) cases for simulations that do not include ACI and the impact of ACI on the past (bottom left) and future (bottom right) changes. All units are mm/day. Impacts of ACI on past and future precipitation are not $95 \%$ significant.

Table 6. Global mean $\mathrm{CH}_{4}$ lifetime (years) for each of the sensitivity simulations described in Table 2 . The percentage change relative to the relevant present day simulation is indicated.

\begin{tabular}{lc}
\hline Simulation & Global annual mean $\mathrm{CH}_{4}$ lifetime \\
\hline Sim PI_ACI & $8.53(-11.5 \%)$ \\
Sim PD_ACI & 9.64 \\
Sim 2050_ACI & $9.85(+2.2 \%)$ \\
Sim PI & $8.81(-0.3 \%)$ \\
Sim PD & 9.83 \\
Sim 2050 & $9.99(+1.6 \%)$
\end{tabular}

Northern Hemisphere where the ACI impacts may be -1 to $-2^{\circ} \mathrm{C}$. The global average impact on the past change amounts to about a $20 \%$ reduction of $-0.13 \pm 0.07^{\circ} \mathrm{C}$. The global impact of including ACI on the future SAT change is small $+0.03 \pm 0.05^{\circ} \mathrm{C}$ and features more complex regional changes including SAT increases in regions where aerosol emissions have decreased (North America, Eurasia) and decreases in regions where aerosol emissions have increased
(Middle East, North Africa). However, the ACI impacts on future SAT are not statistically significant.

\subsection{Impact of $\mathrm{ACI}$ on $\mathrm{J}\left(\mathrm{O}^{1} \mathrm{D}\right)$ photolysis rate}

The impacts of ACI on the past (PD-PI) and future (2050$\mathrm{PD}$ ) changes in $\mathrm{J}\left(\mathrm{O}^{1} \mathrm{D}\right)$ at the surface, important for $\mathrm{O}_{3}$ air quality, and in the mid-troposphere at $500 \mathrm{mb}$ are shown in Fig. 5. For the PD-PI surface change, ACI impose further decreases in $\mathrm{J}\left(\mathrm{O}^{1} \mathrm{D}\right)$ across large regions of the globe. The ACI impacts the PD-PI surface change by about $50 \%$ across the eastern US, 80\% across East Asia and across Europe, the ACI impacts dominate over the PD-PI change. The effects of the future $\mathrm{ACI}$ on the surface change in $\mathrm{J}\left(\mathrm{O}^{1} \mathrm{D}\right)$ are found to be insignificant across North America and Europe since the aerosol loading changes are modest for the scenario that we examine. However, the suppression of $\mathrm{J}\left(\mathrm{O}^{1} \mathrm{D}\right)$ at the surface due to increased ACI is evident across the Middle East and South Asian regions ( $\sim 50-100 \%$ of 2050-PD change). Changes in cloud optical depth (COD) provide the dominant mechanism for the $\mathrm{J}\left(\mathrm{O}^{1} \mathrm{D}\right)$ response to $\mathrm{ACI}$ at the surface level. Thus, decreases (increases) in $\mathrm{J}\left(\mathrm{O}^{1} \mathrm{D}\right)$ when $\mathrm{ACI}$ are 
[PD-PI] SAT (deg C)

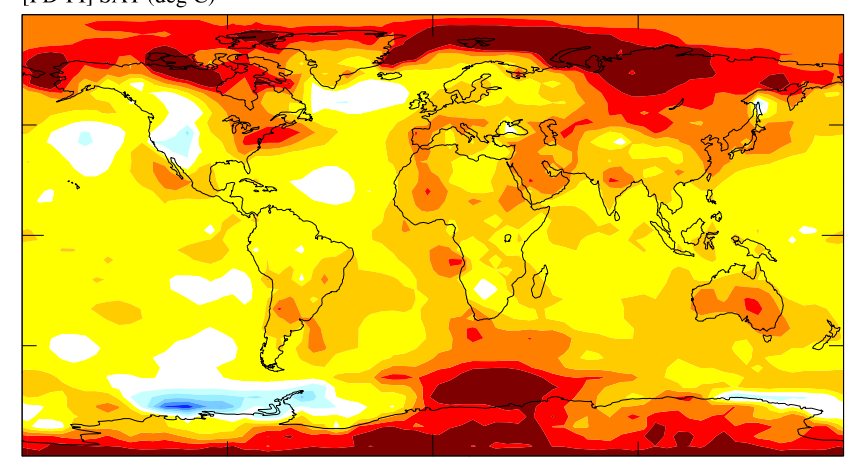

Impact of ACI on [PD-PI] SAT (deg C)

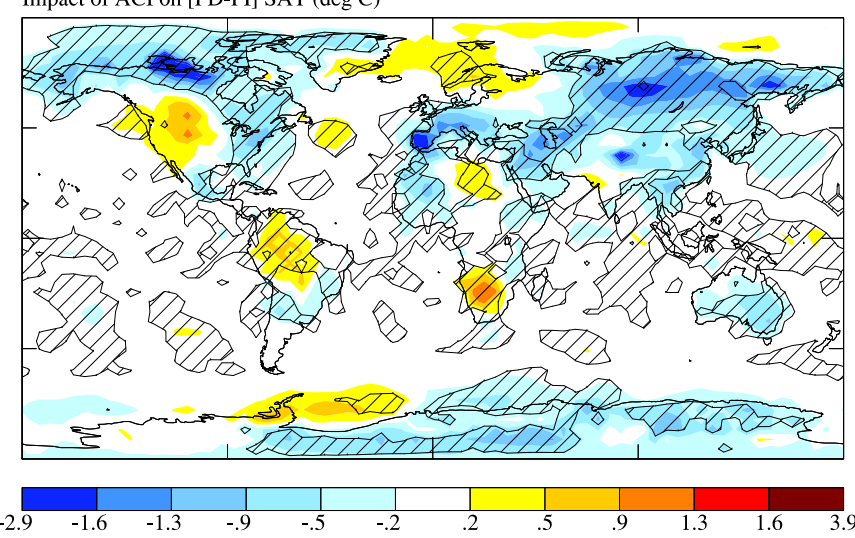

[2050-PD] SAT (deg C)

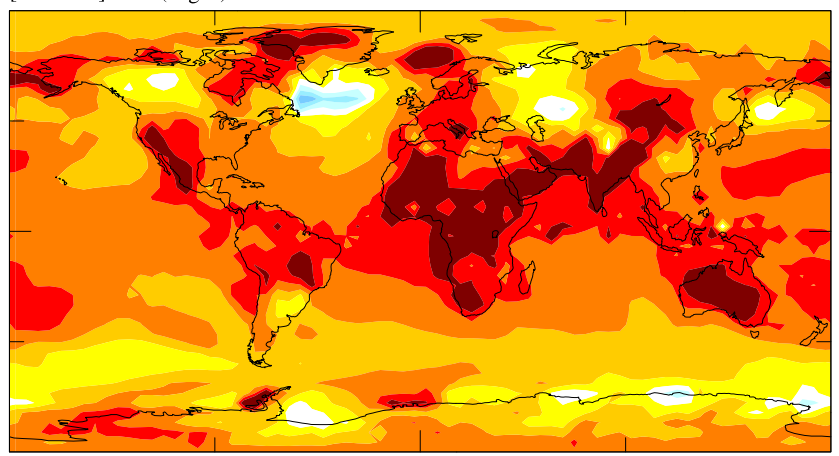

Impact of ACI on [2050-PD] SAT (deg C)

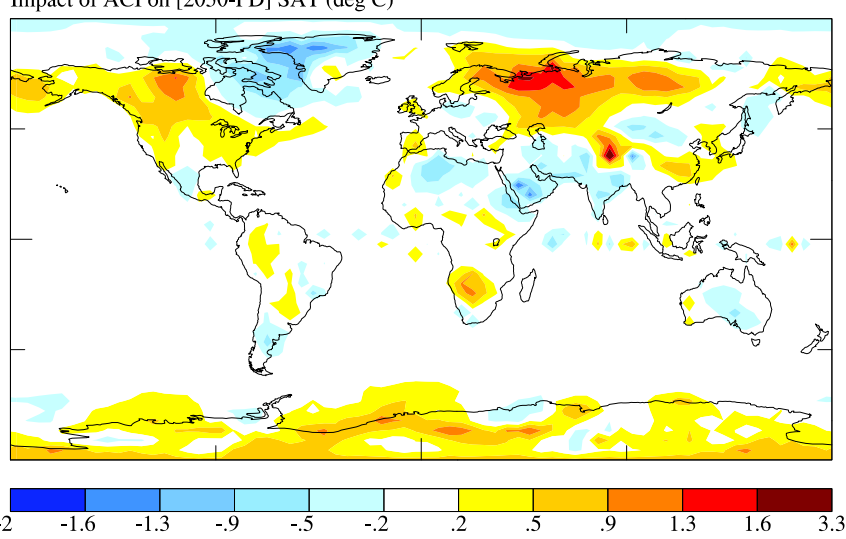

Fig. 4. Annual average surface air temperature (SAT) change for past (top left) and future (top right) cases for simulations that do not include ACI and the impact of ACI on the past (bottom left) and future (bottom right) changes. Hatched regions indicate significance at $95 \%$ confidence. (Impacts of ACI on future SAT are not 95\% significant.) All units are deg C.

included are largely driven by increases (decreases) in COD (Fig. 1). However, in some tropical and Southern Hemisphere regions such as South America and South Africa in the past and future cases and southeastern China in the future case, surface $\mathrm{J}\left(\mathrm{O}^{1} \mathrm{D}\right)$ increases due to $\mathrm{ACI}$ even though COD has increased in those regions. The $\mathrm{J}\left(\mathrm{O}^{1} \mathrm{D}\right)$ response in these regions is determined by a co-located decrease in cloud cover (CC) that exposes greater incoming radiation (Fig. 1). In the mid-troposphere at $500 \mathrm{mb}$, ACI drives enhancements in the $\mathrm{J}\left(\mathrm{O}^{1} \mathrm{D}\right)$ change in tropical and subtropical regions for both time periods that can be $25-50 \%$ of the change for each time period (Fig. 5). These increases at higher altitudes closely follow increases in CDNC (Fig. 1) and therefore are a result of enhanced above cloud radiative scattering.

The effect on $\mathrm{O}_{3}$ of a decrease in the $\mathrm{J}\left(\mathrm{O}^{1} \mathrm{D}\right)$ photolysis channel depends on the background $\mathrm{NO}_{\mathrm{x}}$ concentration. Under low $\mathrm{NO}_{\mathrm{x}}$ conditions, a decrease in $\mathrm{J}\left(\mathrm{O}^{1} \mathrm{D}\right)$ can induce increases in $\mathrm{O}_{3}$ levels. Under more polluted photochemically active regions, the opposite may be true since this chain initiation process also drives the production of $\mathrm{O}_{3}$. The net impact of ACI on past and future surface $\mathrm{O}_{3}$ changes is discussed in Sect. 3.5.
Since the $\mathrm{J}\left(\mathrm{O}^{1} \mathrm{D}\right)$ photolysis channel is the major direct source of $\mathrm{OH}$, the ACI influence on $\mathrm{OH}$ changes mostly follows the spatial patterns of $\mathrm{J}\left(\mathrm{O}^{1} \mathrm{D}\right)$ changes shown in Fig. 5. Thus, there are corresponding decreases in the surface $\mathrm{OH}$ change $(\sim-20 \%)$ over polluted regions due to the ACI effects that somewhat counteract the general increase in surface $\mathrm{OH}$ fields for the PD-PI time period due to $\mathrm{NO}_{\mathrm{x}}$ emissions increases (not shown). Similarly, there are ACI-driven increases in the $\mathrm{OH}$ change at higher altitudes in subtropical regions. In the next section, we discuss further the impacts of $\mathrm{ACI}$ on $\mathrm{OH}$ changes throughout the troposphere.

\subsection{Impact of ACI on zonal mean $\mathrm{OH}$ and global mean $\mathrm{CH}_{4}$ lifetime}

Figure 6 shows the impact of ACI on past and future changes in annual zonal mean $\mathrm{OH}$ throughout the troposphere. The model PD-PI change in $\mathrm{OH}$ is discussed in more detail in Shindell et al. (2003). Briefly, the PD-PI change features lower tropospheric $\mathrm{OH}$ increases in Northern Hemisphere tropical to mid-latitudes due to $\mathrm{NO}_{\mathrm{x}}$ emissions increases at the surface, and more broad decreases in $\mathrm{OH}$ 
Impact of $\mathrm{ACI}$ on $[\mathrm{PD}-\mathrm{PI}] \mathrm{J}\left(\mathrm{O}^{1} \mathrm{D}\right)$ surface

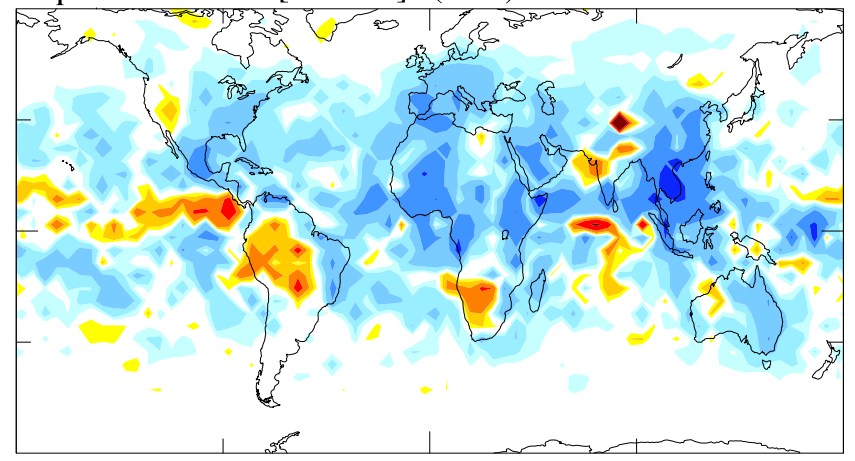

Impact of $\mathrm{ACI}$ on $[\mathrm{PD}-\mathrm{PI}] \mathrm{J}\left(\mathrm{O}^{1} \mathrm{D}\right) 500 \mathrm{mb}$
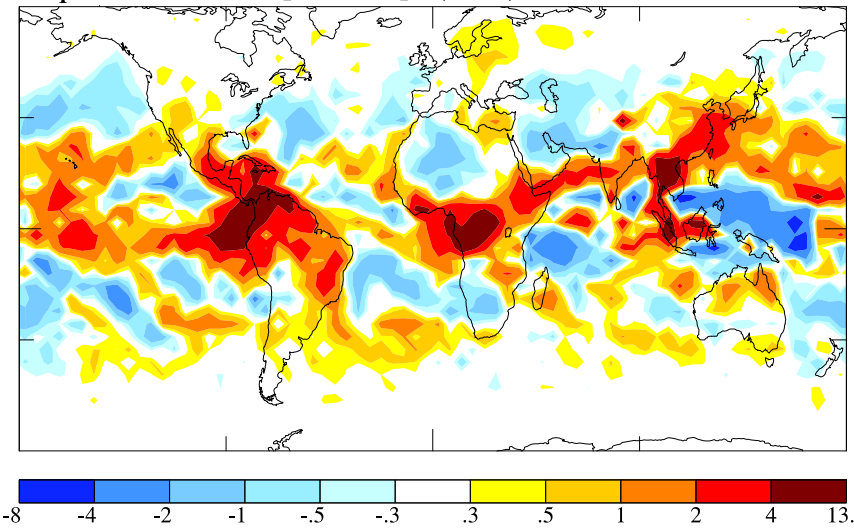

Impact of $\mathrm{ACI}$ on $[2050$ - $\mathrm{PD}] \mathrm{J}\left(\mathrm{O}^{1} \mathrm{D}\right)$ surface

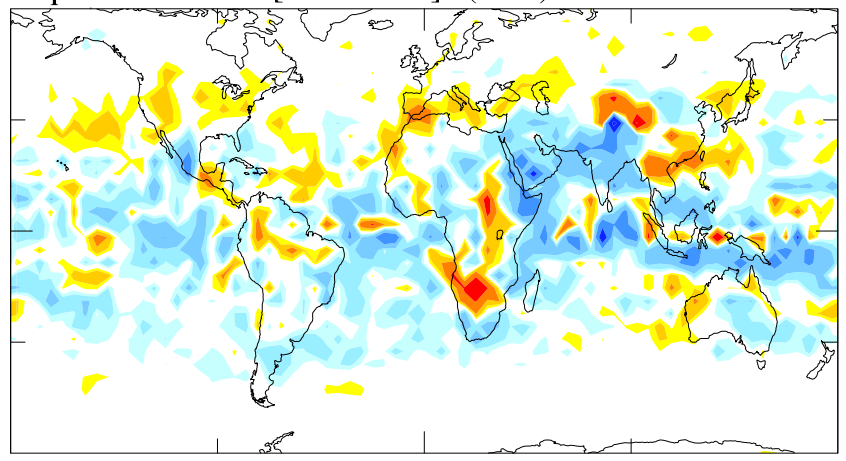

Impact of $\mathrm{ACI}$ on $[2050-\mathrm{PD}] \mathrm{J}\left(\mathrm{O}^{1} \mathrm{D}\right) 500 \mathrm{mb}$
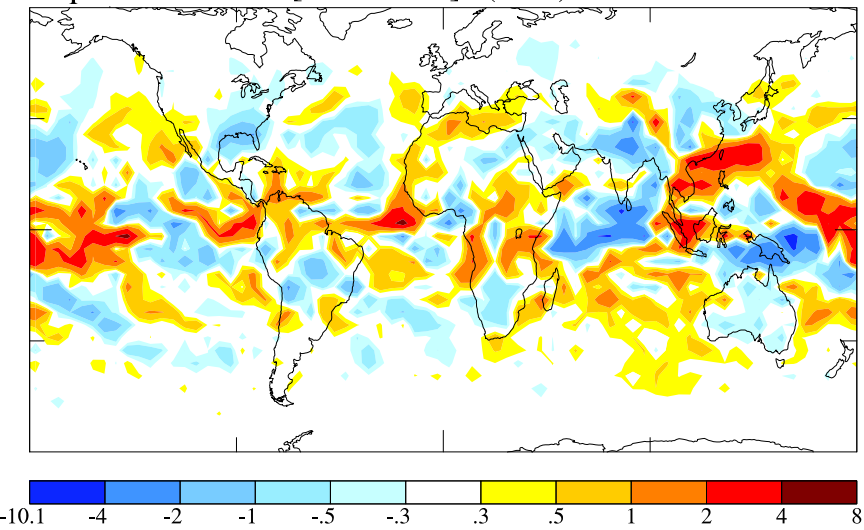

Fig. 5. Impact of ACI on the surface and $500 \mathrm{mb}$ changes in annual average photolysis rate $\mathrm{J}\left(\mathrm{O}^{1} \mathrm{D}\right)$ for the past (left) and future (right) cases. All units are $10^{-7} \mathrm{~s}^{-1}$. Colored regions are $95 \%$ significant.
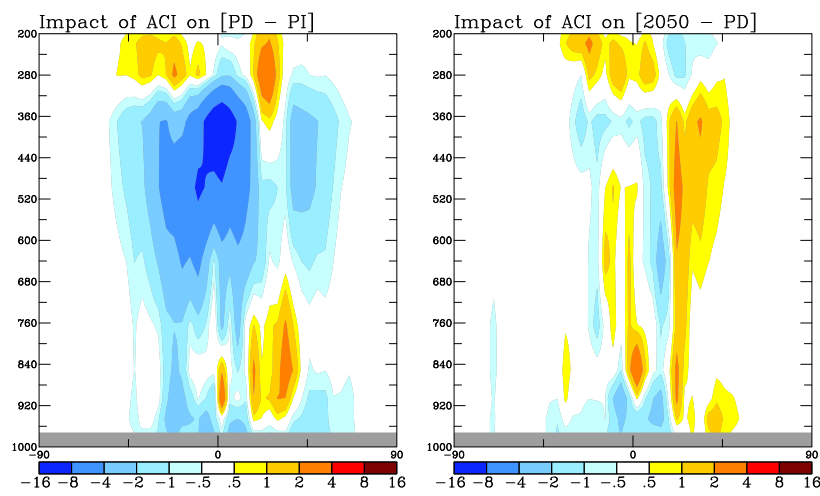

Fig. 6. Impact of ACI on the past (left panel) and future (right panel) changes in annual average zonal mean $\mathrm{OH}$ concentration in $10^{4}$ molecule $\mathrm{cm}^{-3}$.

levels throughout the free troposphere due to increases in carbon monoxide (CO), $\mathrm{CH}_{4}$ and non-methane volatile organic compounds (NMVOC) emissions. Inclusion of the ACI acts to amplify these changes further on the order of $\sim 10 \%$. The largest ACI impact $(\sim-30 \%)$ on the $\mathrm{OH}$ change is in the middle and upper tropical troposphere where $\mathrm{CH}_{4}$ oxidation is important. The suppression in $\mathrm{J}\left(\mathrm{O}^{1} \mathrm{D}\right)$ photolysis rates in the lower troposphere due to enhanced ACI leads to reduced $\mathrm{OH}$ production and therefore decreased oxidation rates near the surface, allowing greater vertical transport of $\mathrm{CO}$ and $\mathrm{NMVOC}$ precursors to the middle and upper troposphere. In consequence, the $\mathrm{OH}$ in this region is decreased further for the PD-PI change when ACI effects are considered. The ACI-induced increases in the $\mathrm{OH}$ changes in the Northern Hemisphere subtropics are partly driven by increases in $\mathrm{J}\left(\mathrm{O}^{1} \mathrm{D}\right)$ at higher altitudes as discussed in the previous section. Increased availability of $\mathrm{NO}_{\mathrm{x}}$ (not shown) due to reduced $\mathrm{HNO}_{3}$ wet deposition (discussed in the following section) also likely plays a role in the $\mathrm{OH}$ enhancements. The impacts of ACI on the 2050-PD change in $\mathrm{OH}$ follow a broadly similar pattern but shifted to lower latitudes in keeping with the precursor emissions shift, but are weaker (only a few percent at most) than past impacts. Temperature changes (Fig. 4) may also have an impact on the $\mathrm{OH}$ changes. The ACI-induced decreases in PD-PI SAT likely slow chemical activity, although it is not easy to discern the net effects of such temperature decreases on $\mathrm{OH}$. 
Past [PD-PI]

Sulfate in-cloud source $\left(\mathrm{mgm}^{-2} \mathrm{yr}^{-1}\right)$

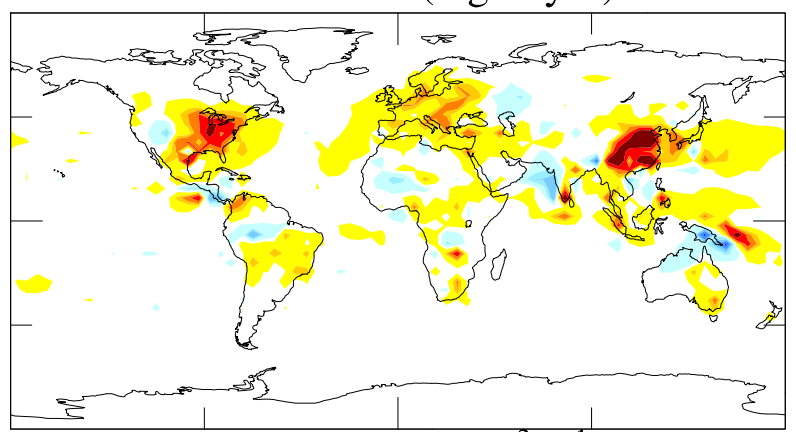

Sulfate wet deposition $\left(\mathrm{mgm}^{-2} \mathrm{yr}^{-1}\right)$

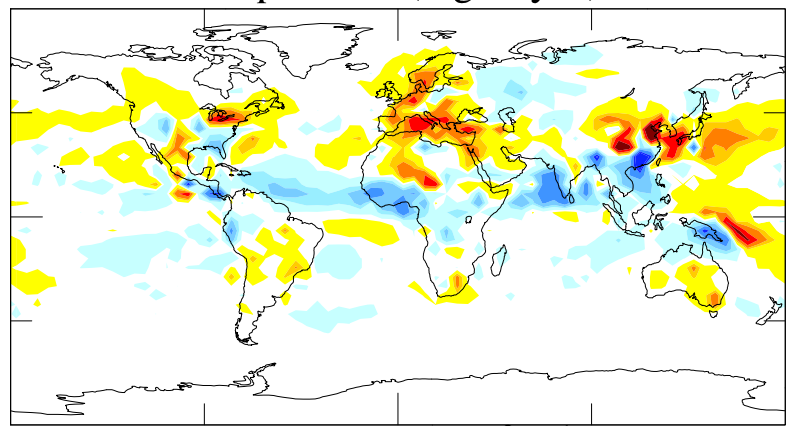

$\mathrm{HNO}_{3}$ wet deposition $\left(\mathrm{mgm}^{-2} \mathrm{yr}^{-1}\right)$

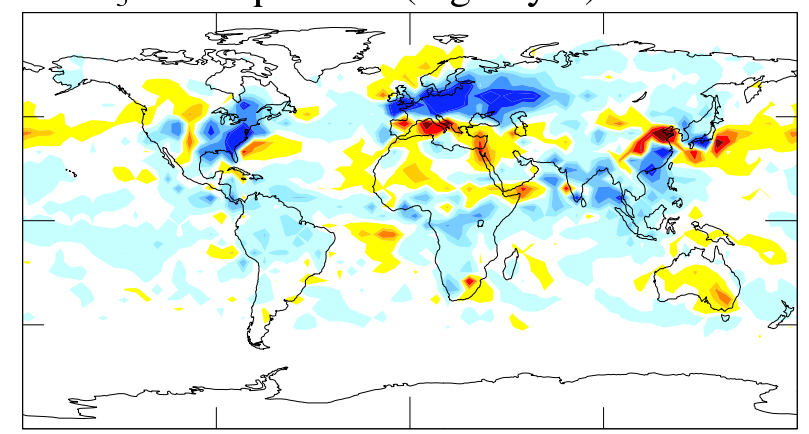

Future [2050-PD]

Sulfate in-cloud source $\left(\mathrm{mgm}^{-2} \mathrm{yr}^{-1}\right)$
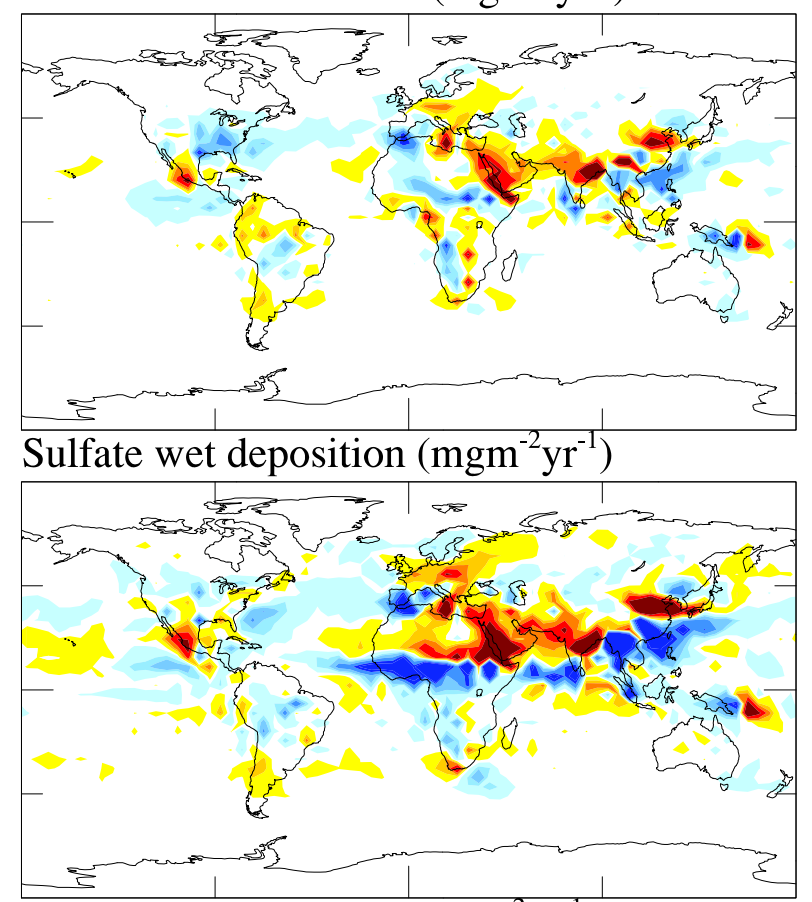

$\mathrm{HNO}_{3}$ wet deposition $\left(\mathrm{mgm}^{-2} \mathrm{yr}^{-1}\right)$

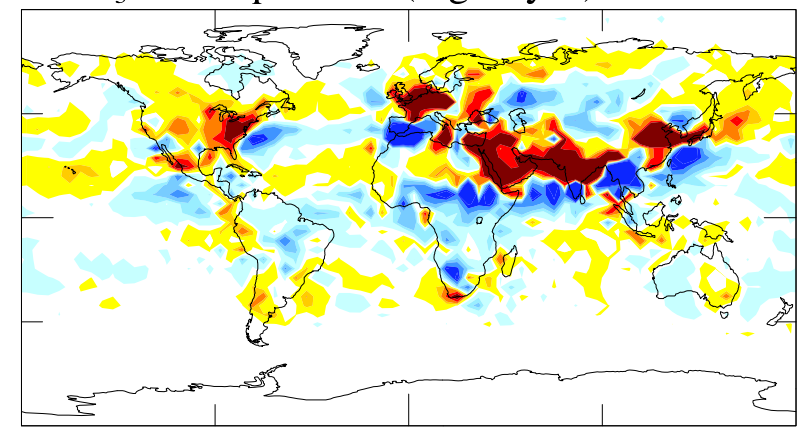

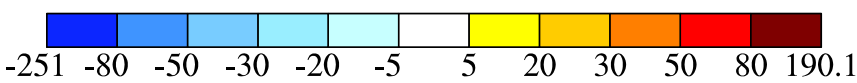

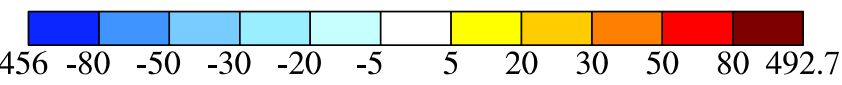

Fig. 7. Impact of ACI on the rates of sulfate in-cloud production, sulfate wet deposition and $\mathrm{HNO}_{3}$ wet deposition for past (left column) and future (right column) cases in $\mathrm{mg} \mathrm{m}^{-2} \mathrm{yr}^{-1}$. Colored regions are $95 \%$ significant.

The global mean $\mathrm{CH}_{4}$ lifetime (calculated as [global mean tropospheric $\mathrm{CH}_{4}$ mass $(\mathrm{kg}) / \mathrm{global}$ mean tropospheric loss rate with respect to $\mathrm{OH}(\mathrm{kg} / \mathrm{s})]$ for each simulation and time period is shown in Table 6. At all 3 time periods the influence of including ACI in the model is to reduce the global mean $\mathrm{CH}_{4}$ lifetime by about 2-3\% relative to simulations that do not include $\mathrm{ACI}$ in the same time slice. Global mean $\mathrm{CH}_{4}$ lifetime increases from PI to PD and to a lesser extent from PD to 2050 due to increases in emissions of $\mathrm{CO}$ and other NMVOCs that compete with $\mathrm{CH}_{4}$ for $\mathrm{OH}$ reaction, and increases in emissions of $\mathrm{CH}_{4}$ itself, despite co-increases in $\mathrm{NO}_{\mathrm{x}}$ emissions that tend to recycle $\mathrm{OH}$ radicals and decrease the $\mathrm{CH}_{4}$ lifetime. Inclusion of ACI enhances the past and future increases in $\mathrm{CH}_{4}$ lifetime by about $10 \%$ (1.1 versus 1.0 years) for the past case and $30 \%$ for the future case $(0.21$ versus 0.16 years). A previous model study attributed the observed decline in the $\mathrm{CH}_{4}$ growth rate between 1990 and 2004 to a $1.6 \%$ reduction in the $\mathrm{CH}_{4}$ lifetime ( 0.17 years) mainly due to $\mathrm{OH}$ increases driven by increases in lightning $\mathrm{NO}_{\mathrm{x}}$ (Fiore et al., 2006). The substantial response of the change in $\mathrm{CH}_{4}$ lifetime to $\mathrm{ACI}$ found here suggests that changing aerosol-cloud effects may play a significant role in influencing the $\mathrm{CH}_{4}$ lifetime and need to be considered in studies of $\mathrm{CH}_{4}$ trends. 

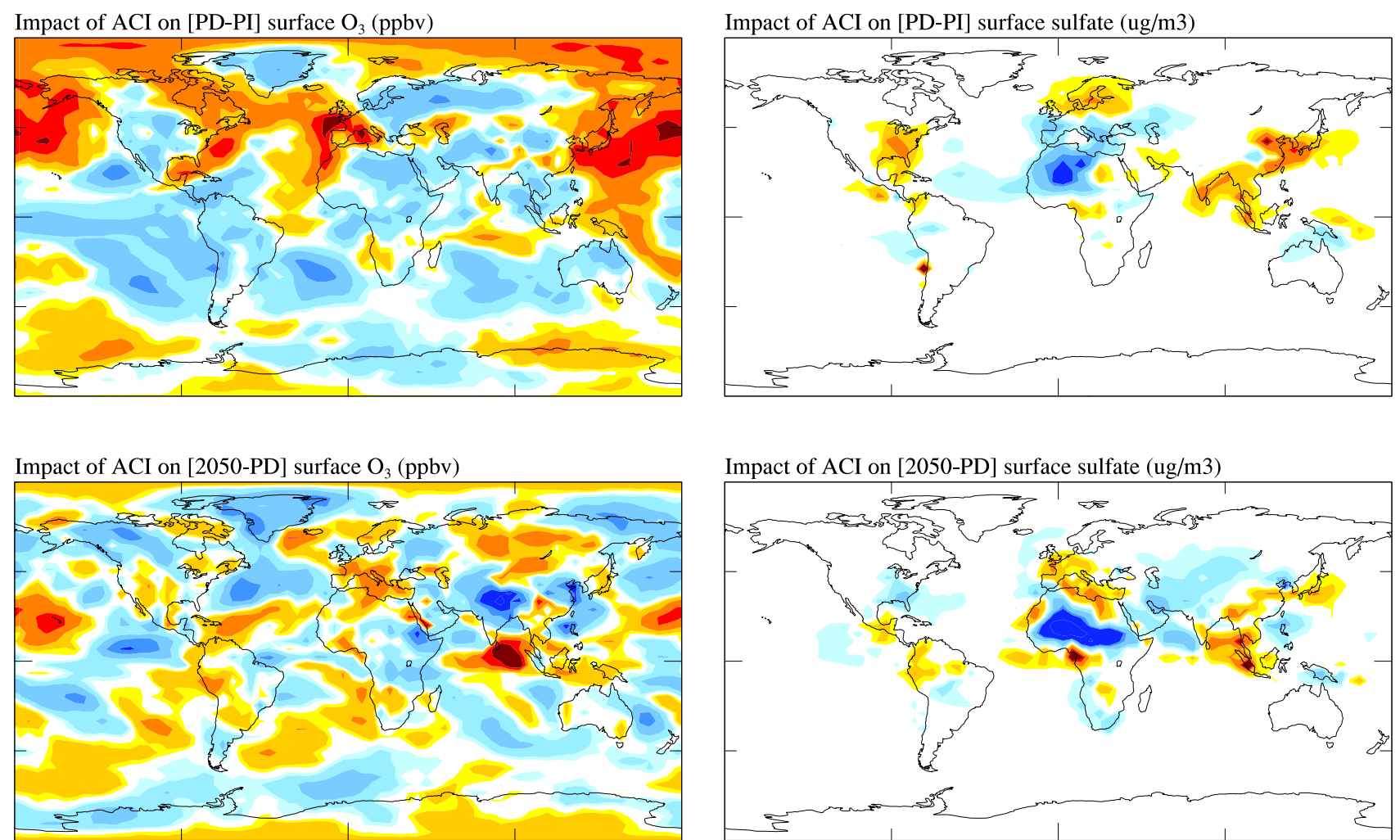

Impact of ACI on [2050-PD] surface sulfate (ug/m3)
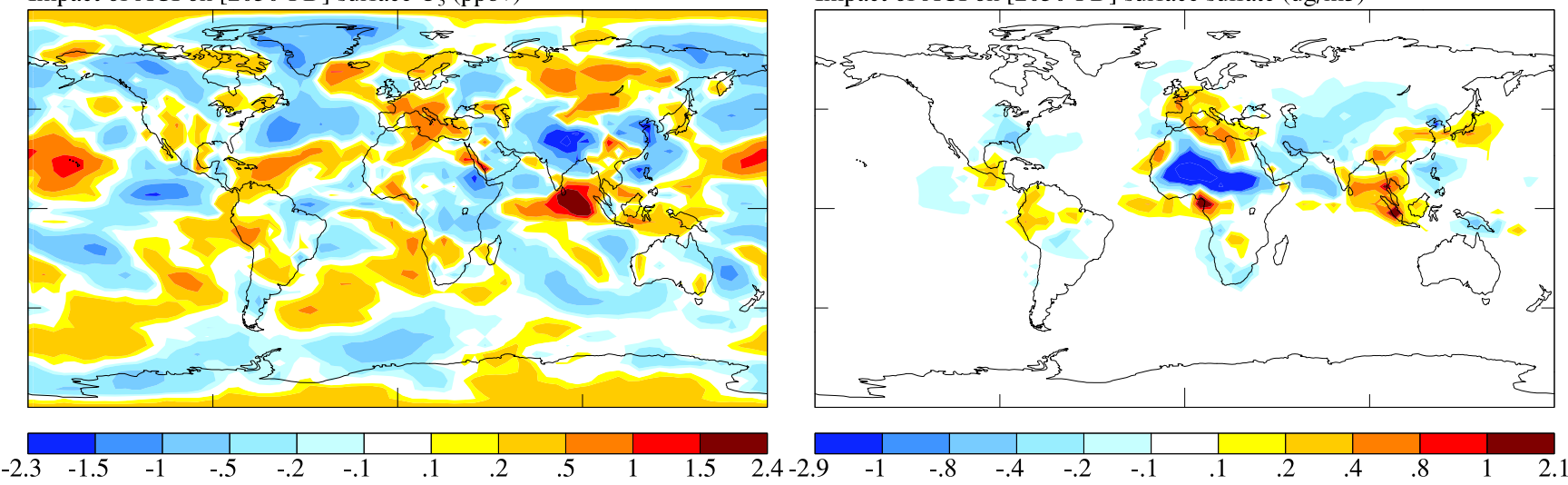

Fig. 8. Impact of ACI on past (PD-PI) and future (2050-PD) changes in surface $\mathrm{O}_{3}$ in ppbv (left) and surface sulfate in $\mu \mathrm{g} \mathrm{m}{ }^{-3}$ (right). Colored regions are $95 \%$ significant.

\subsection{Impact of ACI on sulfate in-cloud production and wet deposition}

The influences of ACI on the past and future changes in sulfate in-cloud production, wet deposition and $\mathrm{HNO}_{3}$ wet deposition are shown in Fig. 7. Inclusion of ACI in the PDPI case drives larger increases in in-cloud sulfate production across polluted regions where there have been aerosolinduced increases in CDNC, LWP and COD. This enhancement in sulfate production in clouds amounts to around 15$20 \%$ of the PD-PI change across eastern US and East Asia $\left(\sim+50-100 \mathrm{mg} \mathrm{m}^{-2} \mathrm{yr}^{-1}\right)$ due to ACI effects alone.

In general, though not in every case, the impacts of ACI on changes in wet deposition map the influence on precipitation (Fig. 3) such that in the regions where aerosol pollution emissions increase and ACI drive decreases in rainfall, precursor wet deposition decreases. There are compensating increases in wet deposition downwind and where the rainfall has increased. Exactly the opposite pattern occurs in regions where aerosol emissions decrease, especially evident in the future case. Since the tracer fate is ultimately wet removal from the atmosphere, the ACI effects on wet deposition appear to displace precursor washout away from source regions.
Thus, for the past case, in the immediate location of the pollution sources in the eastern US and China, the ACI drive decreases in sulfate wet deposition that represent only 5$10 \%$ of the PD-PI change. However, in response to the enhanced in-cloud production, there are ACI-driven increases in sulfate wet deposition further north of the source regions and across Europe $\left(\sim+50-100 \mathrm{mg} \mathrm{m}^{-2} \mathrm{yr}^{-1}\right)$. The PD-PI increase in $\mathrm{HNO}_{3}$ wet deposition rate is dampened due to ACI effects up to $10-15 \%$ across polluted source regions $\left(\sim-100 \mathrm{mg} \mathrm{m}^{-2} \mathrm{yr}^{-1}\right)$. Over Europe, where ACI causes increases in rainfall, $\mathrm{HNO}_{3}$ wet deposition decreases. Therefore, this effect is most likely due to a decrease in the production rate of $\mathrm{HNO}_{3}$ due to reductions in $\mathrm{J}\left(\mathrm{O}^{1} \mathrm{D}\right)$ that deplete $\mathrm{OH}$ levels there. A corollary is that the notorious acid deposition problem due to industrialization in the past century in the northern forests across Europe and northeastern US was made worse by ACI in the case of sulfate but lessened by $\mathrm{ACI}$ in the case of $\mathrm{HNO}_{3}$. Unlike for sulfate aerosol, if the $\mathrm{HNO}_{3}$ lifetime with respect to washout is lengthened, the $\mathrm{HNO}_{3}$ may be photolyzed such that the reactive nitrogen is re-released and available to participate in $\mathrm{O}_{3}$ photochemistry.

For the future 2050 A1B scenario that we examine, the projected decreases in aerosol-loading and ACI over North 
America and Europe are only modest and correspondingly the model suggests weaker impacts than for the past change on precursor washout and sulfate in-cloud production in these regions (Fig. 7). There is a dampening of in-cloud sulfate production across the US and movement of $\mathrm{HNO}_{3}$ wet deposition back to the source regions due to ACI effects on the 2050-PD change that amounts to around $10 \%$ of the future change. ACI driven enhancements in in-cloud sulfate production $(\sim+20 \%$ of future change) are localized in source regions along the northeastern African coastline. Large and significant effects occur over Africa, the Middle East and South Asia where there are large increases in $\mathrm{SO}_{2}$ emissions and thus aerosol loading. Fossil fuel and biofuel aerosoldriven increases in CDNC and COD in Central Africa cause marked dampening ( $\sim-20 \%$ of the 2050 -PD change) in the local wet deposition of sulfate and $\mathrm{HNO}_{3}$, which is displaced across the Middle East and South Asian regions where there are enhancements up to $50-100 \%$ of the future change due entirely to ACI effects. This ACI-driven displacement of acid deposition adds new dimensions and complications to transboundary pollution problems.

\subsection{Impact of ACI on surface air quality}

The resultant ACI effects on annual average surface $\mathrm{O}_{3}$ and sulfate for the past and future changes are complex (Fig. 8). Enhanced ACI for the PD-PI change leads to enhanced surface $\mathrm{O}_{3}$ in outflow regions from the major industrialized continental areas (Western Europe, Western Atlantic, western Pacific) that is about $1-2$ ppbv or up to $10-20 \%$ of the past change on the annual average. This effect on surface $\mathrm{O}_{3}$ may be driven by several factors including: (1) suppression of surface level $\mathrm{J}\left(\mathrm{O}^{1} \mathrm{D}\right)$ which is a sink for $\mathrm{O}_{3}$ under low $\mathrm{NO}_{\mathrm{x}}$ conditions (2) reduction in precursor washout, e.g. $\mathrm{HNO}_{3}$ that increases the availability of $\mathrm{NO}_{\mathrm{x}}$ radicals for $\mathrm{O}_{3}$ formation (3) temperature changes that affect reaction rates. A more quantitative attribution is difficult due to unavailability of reaction rate diagnostics in these particular model simulations. Tropospheric $\mathrm{O}_{3}$ is well known to be highly buffered and relatively robust to perturbation. A recent multi-model intercomparison study found that $20 \%$ decreases in all $\mathrm{O}_{3}$ precursors across major source regions exerted at most a $\sim 1 \mathrm{ppbv}$ decrease in local surface $\mathrm{O}_{3}$ (Fiore et al., 2009). The ACI impacts on surface $\mathrm{O}_{3}$ changes are therefore comparable to, or larger than, the impact of $20 \%$ reductions in all local $\mathrm{O}_{3}$ precursor emissions.

Similarly, for the 2050-PD change, enhanced ACI drives an increase in surface $\mathrm{O}_{3}$ change in the outflow region from South Asia, representing about $50 \%$ of the future change there. The 2050 A1B scenario projects only modest decreases in aerosol loading over North America and Europe relative to $\mathrm{PD}$. Hence, there are only relatively weak $\mathrm{ACI} \mathrm{im}$ pacts on the future $\mathrm{O}_{3}$ change over these regions for this particular emissions scenario $(<0.5 \mathrm{ppbv})$. Other future scenarios that project more aggressive reductions in precursor emis- sions at these latitudes would likely have larger impacts on $\mathrm{O}_{3}$ through aerosol-induced cloud changes (e.g. IPCC SRES $\mathrm{B} 1, \mathrm{~B} 2)$.

ACI impacts on surface sulfate change reflect both the influences of in cloud production and wet deposition. Past enhancements in ACI drive increases in surface sulfate that are about $10-20 \%$ of the PD-PI change across the eastern US, and up to $\sim 20 \%$ across northern Europe and South East Asia, due to local increases in in-cloud production. For the future case, where ACI is diminished over the eastern US, there are further decreases in surface sulfate up to $50 \%$ of the 2050 PD change. The future ACI drives significant surface sulfate enhancements in tropical latitudes over western Africa and South East Asia ( $\sim 20 \%$ of the future increase). Our model findings suggest that simulation of future changes to particulate air quality must include ACI.

\subsection{Impact of ACI on $\mathrm{O}_{3}$ and aerosol direct radiative forcing}

The effects of including ACI on past and future global annual mean direct forcings are small (Table 5) and appear largely negligible for past changes. In the future case, where pollution emissions are shifted to lower latitudes with higher insolation, inclusion of ACI reduces the magnitude of the sulfate direct forcing, and as a result the net aerosol direct forcing, by $\sim 8 \%$. This reduction in sulfate forcing is driven by enhanced in-cloud sulfate formation when ACI are included in the model. Sulfate formed in aqueous phase has a shorter lifetime and smaller impact on radiative forcing (e.g. Koch et al., 1999). The effect is more pronounced for precursor emissions increases at subtropical latitudes rather than for the past change when the emissions increases occurred at higher latitudes.

\section{Discussion and conclusions}

We performed sensitivity studies with a global atmospheric composition-climate model to assess the impact of aerosols on tropospheric chemistry through their modification on clouds. The model includes coupling between aerosol and $\mathrm{O}_{3}$ chemistry and aerosols and liquid-phase clouds. The time periods that we considered are preindustrial to present day (past) and present day to 2050 (future). The model simulated AIE is $-2.0 \mathrm{Wm}^{-2}$ for PD-PI and $-0.6 \mathrm{Wm}^{-2}$ for 2050-PD. To our knowledge, this is the first global modeling assessment of ACI impacts on changes in $\mathrm{CH}_{4}$ lifetime, in-cloud sulfate production and precursor wet deposition, and surface $\mathrm{O}_{3}$ and fine particulate surface air quality.

Inclusion of ACI substantially impacts changes in global mean $\mathrm{CH}_{4}$ lifetime across both time periods, enhancing the past and future increases by $10 \%$ and $30 \%$, respectively. Inclusion of ACI has only subtle effects on global annual mean $\mathrm{O}_{3}$ and aerosol direct radiative forcing, except for sulfate 
forcing in the future case, which is reduced by $\sim 8 \%$ when ACI are included. More generally, including ACI in the past and future changes has only small impacts on global scales but large and significant effects on regional composition.

In regions where pollution emissions increase, inclusion of aerosol-cloud effects leads to $20 \%$ enhancements in the increases in in-cloud sulfate production. Sulfate wet deposition is enhanced by a similar amount further north of source regions and $\mathrm{HNO}_{3}$ wet deposition is dampened by $15-20 \%$ and displaced away from the source regions. The enhanced incloud sulfate formation leads to larger increases $(\sim 10-30 \%)$ in surface sulfate across polluted regions. For the future case when precursor emissions are reduced over the eastern US, diminished ACI further reduces the surface sulfate change by $\sim 50 \%$. Impacts of ACI on surface $\mathrm{O}_{3}$ changes are on the order of 1-2 ppbv increases in the outflow from polluted source regions (up to $10-20 \%$ of the PI to PD change). In our model, there is little net impact on surface the $\mathrm{O}_{3}$ change between 2050 and PD over North America and Europe because the aerosol decreases are relatively modest over these regions for the A1B scenario.

The results are dependent on the emissions scenarios that we have considered but may be extrapolated to serve as a guide to impact assessment for alternative projections. For example, future worlds with more aggressive aerosol reduction policies, or conversely with substantially greater aerosol emissions, will likely exert larger impacts on surface $\mathrm{O}_{3}$, sulfate and $\mathrm{CH}_{4}$ lifetime than found here.

The major limitations of the study are the large uncertainties associated with the ACI, partly driven by uncertainties in aerosol emission inventories (especially for carbonaceous aerosols), partly due to the parameterizations used to link aerosols with cloud droplet number, and the lack of available observations to assess aerosol-cloud feedbacks. At present it is challenging to provide observational constraints on aerosol-cloud impacts on composition. Next generation satellite data products may provide unprecedented insights into ACI and effects on composition.

Despite these shortcomings, our model sensitivity studies suggest that aerosol-cloud effects are an important feedback on regional-scale cloud processing, surface particulate matter and global scale $\mathrm{CH}_{4}$ lifetime. Based on our model findings, we recommend that projections of future changes to particulate matter air quality and investigation of $\mathrm{CH}_{4}$ trends must consider aerosol-cloud interactions.

Acknowledgements. We thank the NASA Atmospheric Chemistry Modeling and Analysis Program for funding support. We thank the NASA Center for Computational Sciences for computing support. The work at Lawrence Berkeley National Laboratory was supported by the US Department of Energy under Contract No. DE-AC02-05CH11231. S. M. acknowledges funding from the NASA Modeling and Analysis Program

Edited by: J. H. Seinfeld

\section{References}

Albrecht, B.: Aerosols, cloud microphysics, and fractional cloudiness, Science, 245, 1227, 1989.

Bauer, S. E., Koch, D., Unger, N., Metzger, S. M., Shindell, D. T., and Streets, D. G.: Nitrate aerosols today and in 2030: Importance relative to other aerosol species and tropospheric ozone, Atmos. Chem. Phys., 7, 5043-5059, 2007, http://www.atmos-chem-phys.net/7/5043/2007/.

Bell, N., Koch, D., and Shindell, D. T.: Impacts of chemistryaerosol coupling on tropospheric ozone and sulfate simulations in a general circulation model, J. Geophys. Res., 110, D14305, doi:10.1029/2004JD005538, 2005.

Bian, H. and Prather, M. J.: Fast-J2: Accurate simulation of stratospheric photoylsys in global chemical models, J. Atmos. Chem., 41, 281-296, 2002.

Bond, T. C., Streets, D. G., Yarber, K. F., Nelson, S. M., Woo, J.H., and Klimont, Z.: A technology-based global inventory of black and organic carbon emissions from combustion, J. Geophys. Res., 109, D14203, doi:10.1029/2003JD003697, 2004.

Chen, W.-T., Liao, H., and Seinfeld, J. H.: Future climate impacts of direct radiative forcing of anthropogenic aerosols, tropospheric ozone, and long-lived greenhouse gases, J. Geophys. Res., 112, D14209, doi:10.1029/2006JD008051, 2007.

Dentener, F. J. and Crutzen, P. J.: Reaction of $\mathrm{N}_{2} \mathrm{O}_{5}$ on tropospheric aerosols: impact on the global distributions of $\mathrm{NO}_{\mathrm{x}}, \mathrm{O}_{3}$ and $\mathrm{OH}$, J. Geophys. Res., 98, 7149-7163, 1993.

Del Genio, A. D. and Yao, M.-S.: Efficient cumulus parameterization for long-term climate studies: The GISS scheme, in: The Representation of Cumulus Convection in Numerical Models, AMS Meteor. Monograph, edited by: Emanuel, K. A., and Raymond, D. A., 24(46), 181-184, Am. Meteor. Soc., 1993.

Fiore, A. M., Horowitz, L. W., Dlugokencky, E. J., and West, J. J.: Impact of meteorology and emissions on methane trends, 1990-2004, Geophys. Res. Lett., 33, L12809, doi:10.1029/2006GL026199, 2006.

Fiore, A. M., Dentener, F. J., Wild, O., Cuvelier, C., Schultz, M. G., Hess, P., Textor, C., Schulz, M., et al.: Multimodel estimates of intercontinental source-receptor relationships for ozone pollution, J. Geophys. Res., 114, D04301, doi:10.1029/2008JD010816, 2009.

Forster, P., Ramaswamy, V., Artaxo, P., et al.: Changes in atmospheric constituents and in radiative forcing, in Climate Change 2007: The Physical Science Basis Cambridge Univ. Press, New York, USA, 131-215, 2007.

Hansen, J., Sato, Mki., Ruedy, R., et al.: Efficacy of climate forcings, J. Geophys. Res., 110, D18104, doi:10.1029/2005JD005776, 2005.

Koch, D., Menon, S., Del Genio, A., Ruedy, R., Aleinov, I., and Schmidt, G. A.: Dangerous human-made interference with climate: A GISS modelE study, Atmos. Chem. Phys., 7, 22872312, 2007, http://www.atmos-chem-phys.net/7/2287/2007/.

Jones, A., Haywood, J. M., and Boucher, O.: Aerosol forcing, climate response and climate sensitivity in the Hadley Centre climate model, J. Geophys. Res., 112, D20211, doi:10.1029/2007JD008688, 2007.

Kloster, S., Dentener, F., Feichter, J., Raes, F., Lohmann, U., Roeckner, E., and Fischer-Bruns, I.: A GCM study of future climate response to aerosol pollution reductions, Clim. Dynam., doi:10.1007/s00382-009-0573-0, in press, 2009. 
Koch, D., Jacob, D., Tegen, I., Rind, D., and Chin, M.: Tropospheric sulfur simulation and sulfate direct radiative forcing in the Goddard Institute for Space Studies general circulation model, J. Geophys. Res., 104, 23799-23822, doi:10.1029/1999JD900248, 1999.

Koch, D., Schmidt, G. A., and Field, C. V.: Sulfur, sea salt, and radionuclide aerosols in GISS ModelE, J. Geophys. Res., 111, D06206, doi:10.1029/2004JD005550, 2006.

Koch, D., Bond, T. C., Streets, D. Unger, N., and van der Werf, G.: Global impacts of aerosols from particular source regions and sectors, J. Geophys. Res., 112, D02205, doi:10.1029/2005JD007024, 2007.

Koch, D., Menon, S., Del Genio, A., Ruedy, R., Aleinov, I., and Schmidt, G. A.: Distinguishing aerosol impacts on climate over the past century, J. Climate, 2009, in press.

Lohmann, U. and Feichter, J.: Global indirect aerosol effects: A review, Atmos. Chem. Phys., 5, 715-737, 2005, http://www.atmos-chem-phys.net/5/715/2005/.

Liao, H. and Seinfeld, J. H.: Global impacts of gas-phase chemistry-aerosol interactions on direct radiative forcing by anthropogenic aerosols and ozone, J. Geophys. Res., 110, D18208, doi:10.1029/2005JD005907, 2005.

Liu, H., Crawford, J. H., Pierce, R. B., Norris, P., Platnick, S. E., Chen, G., Logan, J. A., Yantosca, R. M., Evans, M. J., Kittaka, C., Feng, Y., and Tie, X.: Radiative effect of clouds on tropospheric chemistry in a global three-dimensional chemical transport model, J. Geophys. Res., 111, D20303, doi:10.1029/2005JD006403, 2006.

Martin, R. V., Jacob, D. J., Yantosca, R. M., Chin, M., and Ginoux, P., Global and regional decreases in tropospheric oxidants from photochemical effects of aerosols, J. Geophys. Res., 108, 4097, doi:10.1029/2002JD002622, 2003.

Menon, S., Del Genio, A. D., Koch, D., and Tselioudis, G.: GCM simulations of the aerosol indirect effect: Sensitivity to cloud parameterization and aerosol burden, J. Atmos. Sci., 59, 692713, doi:10.1175/1520-0469, 2002.

Menon, S. and Rotstayn, L.: The radiative influence of aerosol effects on liquid-phase cumulus and stratus clouds based on sensitivity studies with two climate models, Climate Dynamics, 27, 345-356, 2006.

Menon, S. and Del Genio, A. D.: Evaluating the impacts of carbonaceous aerosols on clouds and climate, In: Human-Induced Climate Change: An Interdisciplinary Assessment, edited by: Schlesinger, M. E., Kheshgi, H., Smith, J. B., de la Chesnaye, F. C., Reilly, J. M., Wilson, T., and Kolstad, C., Cambridge University Press, pp. 34-48, 2007.

Menon, S., Unger, N., Koch, D., Francis, J., Garrett, T., Sednev, I., Shindell, D., and Streets, D.: Aerosol climate effects and air quality impacts from 1980 to 2030, Environ. Res. Lett., 3, 024004, doi:10.1088/1748-9326/3/2/024004, 2008a.

Menon, S., Del Genio, A. D., Kaufman, Y., Bennartz, R., Koch, D., Loeb, N., and Orlikowski, D.: Analyzing signatures of aerosolcloud interactions from satellite retrievals and the GISS GCM to constrain the aerosol indirect effect, J. Geophys. Res., 113, D14S22, doi:10.1029/2007JD009442, 2008b.

Olivier, J. G. J. and Berdowski, J. J. M.: Global emissions sources and sinks, in The Climate System, edited by: Berdowski, J., Guicherit, R., and Heij, B. J., 33-78, A. A. Balkema, Brookfield, VT, USA, 2001.
Rayner, N. A., Parker, D. E., Horton, E. B., Folland, C. K., Alexander, L. V., Rowell, D. P., Kent, E. C., and Kaplan, A.: Global analyses of sea surface temperature, sea ice, and night marine air temperature since the late nineteenth century, J. Geophys. Res., 108(D14), 4407, doi:10.1029/2002JD002670, 2003.

Rotstayn, L. D. and Liu, Y.: A smaller global estimate of the second indirect aerosol effect, Geophys. Res. Lett., 32, L05708, doi:10.1029/2004GL021922, 2005.

Schmidt, G. A., Ruedy, R., Hansen, J. E., et al.: Present day atmospheric simulations using GISS ModelE: Comparison to in-situ, satellite and reanalysis data, J. Clim., 19, 153-192, 2006.

Shindell, D. T., Faluvegi, G., and Bell, N.: Preindustrial-to-presentday radiative forcing by tropospheric ozone from improved simulations with the GISS chemistry-climate GCM, Atmos. Chem. Phys., 3, 1675-1702, 2003,

http://www.atmos-chem-phys.net/3/1675/2003/.

Shindell, D. T., Faluvegi, G., and Emmons, L. K.: Inferring carbon monoxide pollution changes from space-based observations, J. Geophys. Res., 110, D23303, doi:10.1029/2005JD006132, 2005.

Shindell, D. T., Faluvegi, G., Unger, N., Aguilar, E., Schmidt, G. A., Koch, D. M., Bauer, S. E., and Miller, R. L.: Simulations of preindustrial, present-day, and 2100 conditions in the NASA GISS composition and climate model G-PUCCINI, Atmos. Chem. Phys., 6, 4427-4459, 2006, http://www.atmos-chem-phys.net/6/4427/2006/.

Shindell, D. T., Faluvegi, G., Bauer, S. E., Koch, D., Unger, N., Menon, S., Miller, R. L., Schmidt, G. A., and Streets, D. G.: Climate response to projected changes in short-lived species under the A1B scenario from 2000-2050 in the GISS climate model, J. Geophys. Res., 112, D20103, doi:10.1029/2007JD008753, 2007.

Stevenson, D. S., Dentener, F. J., Schultz, M. G., et al.: Multimodel ensemble simulations of present-day and nearfuture tropospheric ozone, J. Geophys. Res., 111, D08301, doi:10.1029/2005JD006338, 2006.

Tie, X., Emmons, L., Horowitz, L., Brasseur, G., Ridley, B., Atlas, E., Stroud, C., Hess, P., Klonecki, A., Madronich, S., Talbot, R., and Dibb, J.: Effect of sulfate aerosol on tropospheric $\mathrm{NO}_{\mathrm{x}}$ and ozone budgets: Model simulations and TOPSE evidence, J. Geophys. Res., 108(D4), 8364, doi:10.1029/2001JD001508, 2003.

Twomey, S. A.: Aerosols, clouds and radiation, Atmos. Environ., 25A, 2435-2442, 1991.

Unger, N., Shindell, D. T., Koch, D. M., and Streets, D. G.: Cross influences of ozone and sulfate precursor emissions changes on air quality and climate, Proc. Natl. Acad. Sci., 103, 4377-4380, doi:10.1073pnas.0508769103, 2006a.

Unger, N., Shindell, D. T., Koch, D. M., Amann, M., Cofala, J., and Streets, D. G.: Influences of man-made emissions and climate changes on tropospheric ozone, methane and sulfate at 2030 from a broad range of possible futures, J. Geophys. Res., 111, D12313, doi:10.1029/2005JD006518, 2006b.

Wu, S., Mickley, L. J., Leibensperger, E. M., Jacob, D. J., Rind, D., and Streets, D. G.: Effects of 2000-2050 global change on ozone air quality in the United States, J. Geophys. Res., 113, D06302, doi:10.1029/2007JD008917, 2008. 